Florida International University FIU Digital Commons

9-14-1990

\title{
Potential rates of methanogenesis in peat and marl sawgrass wetlands in the Florida Everglades
}

Dave S. Bachoon

Florida International University

DOI: $10.25148 /$ etd.FI14050402

Follow this and additional works at: https://digitalcommons.fiu.edu/etd

Part of the Biology Commons

\section{Recommended Citation}

Bachoon, Dave S., "Potential rates of methanogenesis in peat and marl sawgrass wetlands in the Florida Everglades" (1990). FIU

Electronic Theses and Dissertations. 1362.

https://digitalcommons.fiu.edu/etd/1362

This work is brought to you for free and open access by the University Graduate School at FIU Digital Commons. It has been accepted for inclusion in FIU Electronic Theses and Dissertations by an authorized administrator of FIU Digital Commons. For more information, please contact dcc@fiu.edu. 


\begin{abstract}
POTENTIAL RATES OF METHANOGENESIS IN PEAT AND MARL SAWGRASS WETLANDS IN THE FLORIDA EVERGLADES

BY

DAVE BACHOON
\end{abstract}

Methanogenesis was studied in soils from two sawgrass wetlands of the Florida Everglades. Marl soils exhibited a significantly higher potential rate of methanogenesis than peat soils. In these wetlands, methanogenesis: (1) decreased rapidly with increasing soil depth, (2) increased at higher temperatures and lower $\mathrm{Eh}$, (3) was stimulated by organic compounds (cellulose, glucose and acetate), and (4) remained unaffected by added ammonium. Lowering the Eh in the peat and marl soils with sulfide or sulfate stimulated methanogenesis. In January 1990, phosphate caused a significant increase in methanogenesis. The potential rates of methanogenesis decreased to undetectable levels when water levels dropped below the surface, and peaked one month after the start of the wet season. Methanogenesis appeared to be a relatively important process in carbon cycling in marl soils and these soils do not accumulate peat. Therefore, one possible explanation for peat accumulation in sawgrass wetlands may be their low rates of methanogenesis. 
POTENTIAL RATES OF METHANOGENESIS IN PEAT AND MARL SAWGRASS WETLANDS IN THE FLORIDA EVERGLADES

\title{
BY
}

\author{
Dave S. Bachoon
}

\begin{abstract}
A thesis submitted in partial fulfillment of requirements for the degree of
\end{abstract}

\author{
MASTER OF SCIENCE \\ in \\ BIOLOGY
}

at

FLORIDA INTERNATIONAL UNIVERSITY

Committee in charge:

Professor Ronald D. Jones

Professor John C. Makemson

Professor George Dalrymple 
To Professors: Ronald D. Jones

John C. Makemson

George Dalrymple

This thesis, having been approved in respect to form and mechanical execution, is referred to you for judgement upon its substantial merit.

Dean Arthur Herriot

College of Arts and Sciences

The thesis of Dave S. Bachoon is approved.

Professør George Dąrrymple

Professor John C. Makemson

Major Professor, Konald D. Jones

Date of Examination: September 14, 1990 
POTENTIAL RATES OF METHANOGENESIS IN PEAT AND MARL SAWGRASS WETLANDS IN THE FLORIDA EVERGLADES

BY

Dave S. Bachoon

A thesis submitted in partial fulfillment of requirements for the degree of

MASTER OF SCIENCE in BIOLOGY at 


\section{ACKNOWLEDGEMENTS}

I would like to thank all the members of my committee, and in particular my major professor, Dr. Ronald D. Jones for his constant help and advice.

I also want to thank my brother Ronald and his wife June for their encouragement and support. Finally, I wish to thank my parents for their advice and sacrifice during the past years. 
Page

List of tables. . . . . . . . . . . . . . . . . iv List of figures. . . . . . . . . . . . . . . . . v

INTRODUCTION. • • • • • • • . • . • • • • • • • • 1

MATERIALS AND METHODS. . . . . . . . . . . . . . 12

study sites. . . . . . . . . . . . . . . 12

Sampling. . . . . . . . . . . . . . . . 14

Sample processing. . . . . . . . . . . . . 15

Soil preparation. . . . . . . . . . . . 16

Analysis. . . . . . . . . . . . . . . 17

RESULTS. • . . . . . . . . . . . . . . . . . 19

DISCUSSION. • • • • • • • • . • • • • • • • • . 39

CONCLUSIONS. . . . . . . . . . . . . . . . . . 49

REFERENCES. . . . . . . . . . . . . . . . . 51

APPENDICES. . . . . . . . . . . . . . . 56

VITA. . . . . . . . . . . . . . . . . . 62 
1a. Temperature depth profiles of the sample sites in the wetlands. . . . . . . . . . . . . 21

b. Temperature depth profiles of the sample sites in the wetlands. . . . . . . . . . . . . 22

2. Seasonal variations of methanogenesis in peat and marl. . . . . . . . . . . . . . . 38 
Figure

1. Location of study sites: (A) sawgrass wetland with peat soil, (B) sawgrass wetland with marl soil. • . . . . . . . . . . . . . . . 13

2. Time course of methanogenesis in peat and marl soil. . . . . . . . . . . . . . . . 20

3. Methanogenesis, $p H$, and Eh depth profiles in peat and marl. . . . . . . . . . . . . . 23

4 a. Comparison of methanogenesis in peat and marl soils in october following a heavy rainfall. . . 24

b. Comparison of methanogenesis in peat and marl soils 2 weeks after the experiment shown in 4 a. .25 c. Comparison of methanogenesis in peat and marl soils. . . . . . . . . . . . . . . . 26

d. Comparison of methanogenesis in peat and marl soils. • • . . . • . . . . . . . . . . 27

5a. Effects of inorganic compounds on methanogenesis in peat and marl. . . . . . . . . . . . 28

b. Effects of inorganic compounds on methanogenesis in marl. . . . . . . . . . . . . . . . 29

c. Effects of inorganic compounds on methanogenesis in peat and marl. . . . . . . . . . . . 30

6a. Effects of organic compounds on methanogenesis in peat and marl. . . . . . . . . . . . 32 
b. Effects of organic compounds on methanogenesis in peat and marl. . . . . . . . . . . 33

7. Depth profiles of methanogenesis with acetate additions in peat and marl. . . . . . . . 34

8a. Temperature effect on methanogenesis in peat and marl. . . . . . . . . . . . . 36

b. Temperature effect on methanogenesis in peat and marl. . . . . . . . . . . . . 37 


\section{INTRODUCTION}

South Florida contains two major wetland systems, the Everglades and the Big Cypress Swamp. These wetlands are bounded on the east by the Atlantic costal Ridge and on the west by the Gulf of Mexico.

The Everglades system is one of the largest freshwater marshes in North America, formerly occupying an area of about $10,000 \mathrm{~km}^{2}$ (Parker, 1974). An extensive program of drainage, initiated in the early 1900s for the purpose of land reclamation for agriculture caused a loss of approximately 20 to $25 \%$ of the original wetland area (stephens, 1974). The Everglades has a tropical rainy climate with wet, hot summers (June through september) during which 60 to $80 \%$ of the annual precipitation occurs, and dry, mild winters (Hofstetter, 1983). The mean annual precipitation ranges between 1100 and $1650 \mathrm{~mm}$, with wide annual fluctuations from less than 760 to over $2670 \mathrm{~mm}$. The mean annual air temperature is $22^{\circ}$ to $24^{\circ} \mathrm{C}$ with a mean January temperature of $18^{\circ} \mathrm{C}$ and a mean July temperature of $27^{\circ} \mathrm{C}$ (Hoffstetter, 1983). These wetlands are developed on a relatively flat limestone platform, with an average southward slope of $2.8 \mathrm{~cm} \mathrm{~km}^{-1}$ (Gleason and speckman, 1974), which results in slow water flow through the wetlands. Everglades National Park (ENP) occupies an area of about 
$2.5 \times 10^{9} \mathrm{~m}^{2}$ and is located at the southern end of the Everglades system (Olmsted and Loope, 1984). There are four dominant categories of wetlands in this area: (1) wet prairies/sawgrass marsh, (2) wetland forest, (3) high-salinity mangrove swamp, and (4) man made impoundments/disturbed wetlands (Harris et al., 1988). The most common category of these wetlands are wet prairies and sawgrass marshes (Loveless, 1959).

Sawgrass marshes occupy approximately $50 \%$ of the land area in ENP (Loveless, 1959). These areas are inundated by water for varying periods of time, ranging in depth above bedrock from a few centimeters in the dry season to $0.5 \mathrm{~m}$ in the wet season (Hofstetter, 1983). Areas with longer durations of inundation develop thick peat soils $(0.5-2 \mathrm{~m})$, while shallower less inundated areas have marl soils (Gleason and Speckman, 1974). Sawgrass (cladium jamaicense) is the major macrophyte in these wetlands, this plant thrives in poorly aerated organic soils (Loveless, 1959). Sawgrass marl areas are covered by periphyton mats, formed by a community of cyanobacteria, algae and bacteria (Gleason and speckman, 1974). Periphyton mats cause the precipitation of calcium carbonate contributing to the development of marl.

Water flows slowly through the Everglade due to the flatness of the area. The flow rate of the water and its organic content are conducive to the formation of suitable habitats for methanogens and other anaerobic microorganisms. 
Methanogenic bacteria belong to the archaebacteria (Woese et al., 1978) and are defined as strict anaerobes that produce methane gas $\left(\mathrm{CH}_{4}\right)$ (Zeikus, 1977). Although these bacteria are metabolically specialized, as a group they exhibit extreme habitat diversity. Species have been isolated from virtually every habitat in which anaerobic remineralization of organic compounds occurs. These include freshwater and marine sediments, digestive and intestinal tracts of animals, and anaerobic waste digesters (Jones et al., 1987). Physiologically, methanogens are represented by extremely thermophilic, moderately thermophilic and many mesophilic isolates, but there are no psychrophilic isolates (Jones et al., 1987). Methanogens are the most cosmopolitan group of the archaebacteria, they can assimilate a wide range of compounds such as amino acids, urea, sulfide, ammonia and certain species can fix nitrogen (Jarrell and Kalmokoff, 1987; Murray and $\mathrm{zinder,} \mathrm{1984).} \mathrm{All} \mathrm{methanogens} \mathrm{appear} \mathrm{to} \mathrm{require}$ trace amounts of nickel, cobalt, and iron for growth (Jarrell and Kalmokoff, 1987). These bacteria are important in carbon cycling because they are active carbon remineralizors in environments lacking electron acceptors such as $\mathrm{O}_{2}, \mathrm{NO}_{3}$ and $\mathrm{SO}_{4}{ }^{2}$ (Jones et $\underline{\text { al. }}$, 1987).

Methanogens are terminal organisms in the anaerobic microbial food chain, they dramatically influence carbon and electron flow in anaerobic habitats by an interaction termed interspecies hydrogen transfer (Rudd and Taylor, 1980). 
Interspecies hydrogen transfer describes transfer of hydrogen from an $\mathrm{H}_{2}$-producing bacteria to an $\mathrm{H}_{2}$-utilizing bacteria, resulting in more oxidized compounds (Jarrell and Kalamokoff, 1987; Rudd and Taylor, 1980; Zeikus, 1977). Possessing a high affinity for $\mathrm{H}_{2}$, methanogens are effective at reducing the partial pressure of $\mathrm{H}_{2}$ to less than $10^{-3}$ atm (Rudd and Taylor, 1980). The low partial pressure of $\mathrm{H}_{2}$, allows certain groups of bacteria to dispose of electrons by pyridine nucleotidemediated reduction of protons to molecular hydrogen (Jones et al., 1987). This reaction is unfavorable at a high partial pressure of $\mathrm{H}_{2}$. Thus the removal of $\mathrm{H}_{2}$ by methanogens acts as an electron sink and as a result the flow of secondary fermentation is shifted towards the production of more oxidized products, mainly $\mathrm{CO}_{2}$ and acetate (Zeikus, 1977). Consequently, fermentative products such as ethanol, lactate, succinate, propionate and butyrate are oxidized further to acetate and $\mathrm{H}_{2}$. Methanogenesis therefore increases the efficiency of biodegradation or fermentation in anaerobic soils, because of interspecies hydrogen transfer. Theoretically interspecies hydrogen transfer results in (1) increased substrate utilization (2) displacement of unfavorable reaction equilibria (3) increased growth of both methanogens and non-methanogens during their coupled growth (Zeikus, 1977). Methanogens are capable of using a limited number of compounds for growth: $\mathrm{H}_{2}$, formate, acetate, methanol, methylamines, $\mathrm{CO}$ and $\mathrm{CO}_{2}$ (Jones et $\underline{\text { al., }}$ 1987; 
Jerrell and Kalmokoff, 1987). These compounds are normal products of anaerobic fermentation.

In marine sediments sulfate-reducing bacteria can outcompete the methanogens for methanogenic precursors because sulfate-reducers have a higher affinity for acetate and hydrogen, and can use a broader range of substrates than methanogens (Schonheit et al., 1982; Zeikus, 1977). The removal of these compounds by sulfate-reducers restricts their availability to methanogens (Schonheit et al., 1982). Thus in environments which contain abundant sulfate, methanogenesis usually takes place in zones of sulfate depletion (Martens and Berner, 1974). However, this is not always the case, and in certain sulfate rich environments (e.g. salt marsh) methanogenesis and sulfate reduction can coexist (oremland and Polcin, 1987). In saline environments containing abundant plant materials, such as salt marshes, several organic compounds (methylated amines, methanol, dimethyl sulfide), termed "non-competitive" substrates exist for which sulfate reducers do not have as strong an affinity as they do for hydrogen or acetate (Cicerone and oremland, 1988; Kiene et al., 1986). These compounds are derived from osmoregulatory solutes in plants (algae), such as dimethylsulfoniopropionate (Oremland and Polcin, 1982). Methanogens in sediments of this type are adapted to the metabolism of "non-competitive" substrates and can coexist in the same zone as sulfate reduction 
(Cicerone and oremland, 1988). In environments (fresh water systems) were the sulfate concentration is usually low $(<2 \mathrm{mM})$, methanogens are effective competitors for methanogenic precursors (Rudd and Taylor, 1980). Therefore, in most marine environments the most significant terminal anaerobic process is sulfate reduction and in freshwater environments it is methanogenesis (Mountfort and Asher, 1981). Methanogenesis in northern $\left(>40^{\circ} \mathrm{N}\right)$ peatlands is thought to produce about $66 \%$ of the total global $\mathrm{CH}_{4}$ emissions from natural wetlands (Crill et al., 1988). Recent research in the northern peatlands of Minnesota had indicated that methanogenesis rates were very low at the sediment surface and increased to maximum rates at $10 \mathrm{~cm}$ in depth, but at greater depths methanogenesis rates decreased (Crill et al.,1988; Williams and Crawford, 1984). Methanogenesis in these environments increased with increasing temperature $\left(4-30^{\circ} \mathrm{C}\right)$ and was stimulated by glucose and $\mathrm{H}_{2} / \mathrm{CO}_{2}$ (Williams and Crawford, 1984). These peatlands are acidic environments $(\mathrm{pH}<5)$, increasing the $\mathrm{pH}$ in the sediments from 4.2 to 6 increased methanogenesis (Williams and Crawford, 1984). In addition, northern temperate swamps exibit strong seasonal variations in methanogenesis, with highest rates observed in early spring and again in late summer (Wilson et al., 1989). Generally the rates of methanogenesis in these wetlands were positively correlated to soil temperature, water table level and organic matter input (Wilson et al., 1989; Crill et al., 
1988; Williams and Crawford, 1984).

Virtually all methanogens can utilize hydrogen as an energy source, reducing $\mathrm{CO}_{2}$ to $\mathrm{CH}_{4} \cdot$ About one half of the taxonomically described species are capable of autotrophic growth, on $\mathrm{CO}_{2} / \mathrm{H}_{2}$ and there are other species which are obligate methylothrophic methanogens that requires reduced $c_{1}$ compounds for growth (Jones et al., 1987). Most strains, however, were stimulated by acetate (Jarrell and Kalmokoff, 1987). In pure culture methanogens do not seem to form methane from compounds more complex than acetate (Rudd and Taylor, 1980). In most instances 70-75\% of the methane produced in sludge digestors and fresh water sediments was derived from acetate (Cappenbeg, 1976; Rudd and Taylor; 1980).

Methane is the ultimate end product of carbon flow from anaerobic decomposition in aquatic freshwater systems. Rudd and Hamilton (1978) have found that up to $55 \%$ of organic carbon is converted to $\mathrm{CH}_{4}$ and $\mathrm{CO}_{2}$ in sediments. $\mathrm{CH}_{4}$ unlike $\mathrm{CO}_{2}$, neither ionizes nor dissolves in water to any appreciable extent (Dinel et $\underline{\text { al }}, 1$ 1988). It is a relatively mobile gas and can move quickly to the atmosphere, therefore considerable amounts of carbon is lost from aquatic systems as $\mathrm{CH}_{4}$ gas instead of as $\mathrm{CO}_{2} \cdot \mathrm{CH}_{4}$ produced in aquatic environment has two possible fates (1) it can be oxidized by methylothropic organisms (both aerobically and anaerobically), and (2) it may enter the atmosphere by: bubbling, diffusion, or by transportation through emergent aquatic plants (Holzapfel- 
Pschorn et al., 1985).

In marine sediments there is often a zone of $10 \mathrm{~W} \mathrm{CH}_{4}$ concentration extending approximately 20-100 cm below the sediment-water interface (Rudd and Taylor, 1980). Below this zone the $\mathrm{CH}_{4}$ concentration increases rapidly (Zeikus, 1977; Rudd and Taylor, 1980). Circumstantial evidence has been reported suggesting that this zone may occur because of anaerobic $\mathrm{CH}_{4}$-oxidation by sulfate-reducing bacteria (Zehnder and Brock, 1979; Rudd and Taylor, 1980). The only other known group of bacteria that can oxidize $\mathrm{CH}_{4}$ under anaerobic conditions are the methanogens, however methanogens normally oxidize less than $1 \%$ of the $\mathrm{CH}_{4}$ they produce (Zehnder and Brock, 1979). Although anaerobic $\mathrm{CH}_{4}$-oxidation could be an important process controlling $\mathrm{CH}_{4}$ concentration in the marine environment, it is a relatively unimportant process in freshwater systems (Rudd and Taylor, 1980).

The major contributors to $\mathrm{CH}_{4}$-oxidation in freshwater environments are the aerobic $\mathrm{CH}_{4}$-oxidizing bacteria (Rudd and Taylor, 1980). Maximum rates of $\mathrm{CH}_{4}$-oxidation in these environments occurs at the aerobic/anaerobic interphase (Zeikus, 1977; Rudd and Taylor, 1980). $\mathrm{CH}_{4}$-oxidation rates dramatically influences $\mathrm{CH}_{4}$ concentration, in certain peatland ecosystems between 11 to $100 \%$ of biogenic $\mathrm{CH}_{4}$ is susceptible to biological oxidation (Yavitt and Lang, 1988). In the Everglades peat soils up to $91 \%$ of the maximum potential flux of $\mathrm{CH}_{4}$ was consumed by $\mathrm{CH}_{4}$-oxidation however in marl soils $\mathrm{CH}_{4}^{-}$ 
oxidation was negligible (King et al., 1990). In these wetlands emergent aquatic plants appear to stimulate $\mathrm{CH}_{4}-$ oxidation via root aeration in peat soils (Burke et al., 1988). King et al., (1990) has found that in marl soils there was no $\mathrm{CH}_{4}$-oxidation associated with root aeration. The stimulation of $\mathrm{CH}_{4}$-oxidation via root aeration has also been reported in studies of $\mathrm{CH}_{4}$-oxidation in rice paddies; in these wetlands up to $80 \%$ of the $\mathrm{CH}_{4}$ produced was oxidized in the rhizosphere (Holzapfel-Pschorn et al., 1985). The rate of $\mathrm{CH}_{4}$ flux is affected by: water level, temperature, and aquatic plant density (Burke et al., 1988.; Harris et al., 1988). Generally, $\mathrm{CH}_{4}$ flux from ENP wetlands increases with plant density, water level and increasing temperature (Burke et al., 1988; Baker-Blocker et al., 1977). Similar dependencies on $\mathrm{CH}_{4}$ flux and the former conditions has been established in rice paddies and temperate swamps (Schutz et al, 1989; Wilson et al., 1989). In rice paddies the addition of fertilizers (organic or inorganic), and dry rice straw increased $\mathrm{CH}_{4}$ emissions from these wetlands by $100 \%$ (Holzapfel-Pschorn et al., 1989). Disturbed wetlands (impoundments, canals etc.) in southern Florida, which contain high concentration of agricultural waste (nitrates and phosphates) with permanent surface water, emitted $\mathrm{CH}_{4}$ at $50 \%$ higher rates than the natural wetlands in the same area (Harris et al., 1988). The qualitative response of $\mathrm{CH}_{4}$ flux from natural wetland ecosystems to any single variable (for 
example soil temperature) based on a few sites defies global extrapolation because numerous factors interact to influence methanogenesis and gas transport.

Methane is an important gas in atmospheric chemistry and global climate. It is the most abundant organic compound in the atmosphere and the second most important compound contributing to the "green house effect" (Cicerone and Oremland, 1988). Recent reports indicate that atmospheric methane concentration has increased by $0.78 \%$ per year between May 1983 and April 1985 (Steele et al, 1987). The three main sources of atmospheric $\mathrm{CH}_{4}$ are natural wetlands (forested and nonforested bogs, forested and nonforested swamps, tundra and alluvia formations), rice paddies and enteric fermentation (animals); the annual $\mathrm{CH}_{4}$ production rates from these sources are 115,110 and $80 \mathrm{Tg} \mathrm{CH}_{4} \mathrm{yr}^{-1}\left(\mathrm{Tg}=10^{12} \mathrm{~g}\right)$ (Cicerone and oremland, 1988). The total annual flux of $\mathrm{CH}_{4}$ has been estimated as $540 \mathrm{Tg} \mathrm{CH} \mathrm{Yr}^{-1}$ (Cicerone and oremland, 1988). Globally, the Everglades system is a relatively poor source of atmospheric $\mathrm{CH}_{4}$, contributing less than $0.5 \mathrm{Tg} \mathrm{CH}_{4} \mathrm{yr}^{-1}$ (Burke et al., 1988). However, recent research by Harris et al. (1988) indicate that $\mathrm{CH}_{4}$ emissions in south Florida has increased by $26 \%$ between 1900 and 1973. This increase resultes from human development in the area (impoundments and disturbed wetlands) which can produce $\mathrm{CH}_{4}$ at much higher rates than the natural wetlands they replaced (Harris et al., 1988). Urban and ruminant sources of $\mathrm{CH}_{4}$ contribute approximately $23 \%$ 
of the total regional source. The dominant sources of $\mathrm{CH}_{4}$ emissions in this area are from wet prairies and sawgrass marshes (Harris et al., 1988).

The important roles of the methanogenic food chain in remineralization of organic compounds and as a terminal step in carbon reduction in anaerobic freshwater environments lead to the hypothesis of this study, that methanogenesis was an important process in carbon cycling in the sawgrass wetlands. The purposes of this work was to study methanogenesis in two soil types, peat and marl; and by comparison, establish if the rates of methanogenesis are correlated to the level of organic carbon accumulation in the sawgrass wetlands of the Everglades. Selected parameters $\left(\mathrm{CH}_{4}\right.$ production, redox potential, $\mathrm{pH}$, temperature, substrate concentrations) and amendment experiments were used during the course of this study . 


\section{MATERIALS AND METHODS}

\section{STUDY AREA}

Two sawgrass wetlands were chosen for this research that were accessible by car and that contained different soil types (peat and marl).

Site $A$

This sawgrass marsh was located in Shark River Slough (Fig. 1), and was inundated by water for most of the year. However, 1989 was an atypically dry year in South Florida, therefore, for a few months during the winter dry season the marsh was dry. The soil was composed of sawgrass peat, covered by dense strands of sawgrass (cladium jamaicense) up to $2 \mathrm{~m}$ high. Water level varied between $15 \mathrm{~cm}$ and $40 \mathrm{~cm}$ for most of the year.

\section{Site $B$}

This sawgrass prairie (Fig. 1) was seasonally flooded and its soil was composed of marl. The marl was covered by periphyton mats. Shorter sawgrass $(0.5 \mathrm{~m})$ grew in lower density compared to site $A$. Water level varied between $10 \mathrm{~cm}$ to $35 \mathrm{~cm}$ during the wet season and dropped to $0 \mathrm{~cm}$ for most of the dry season. 


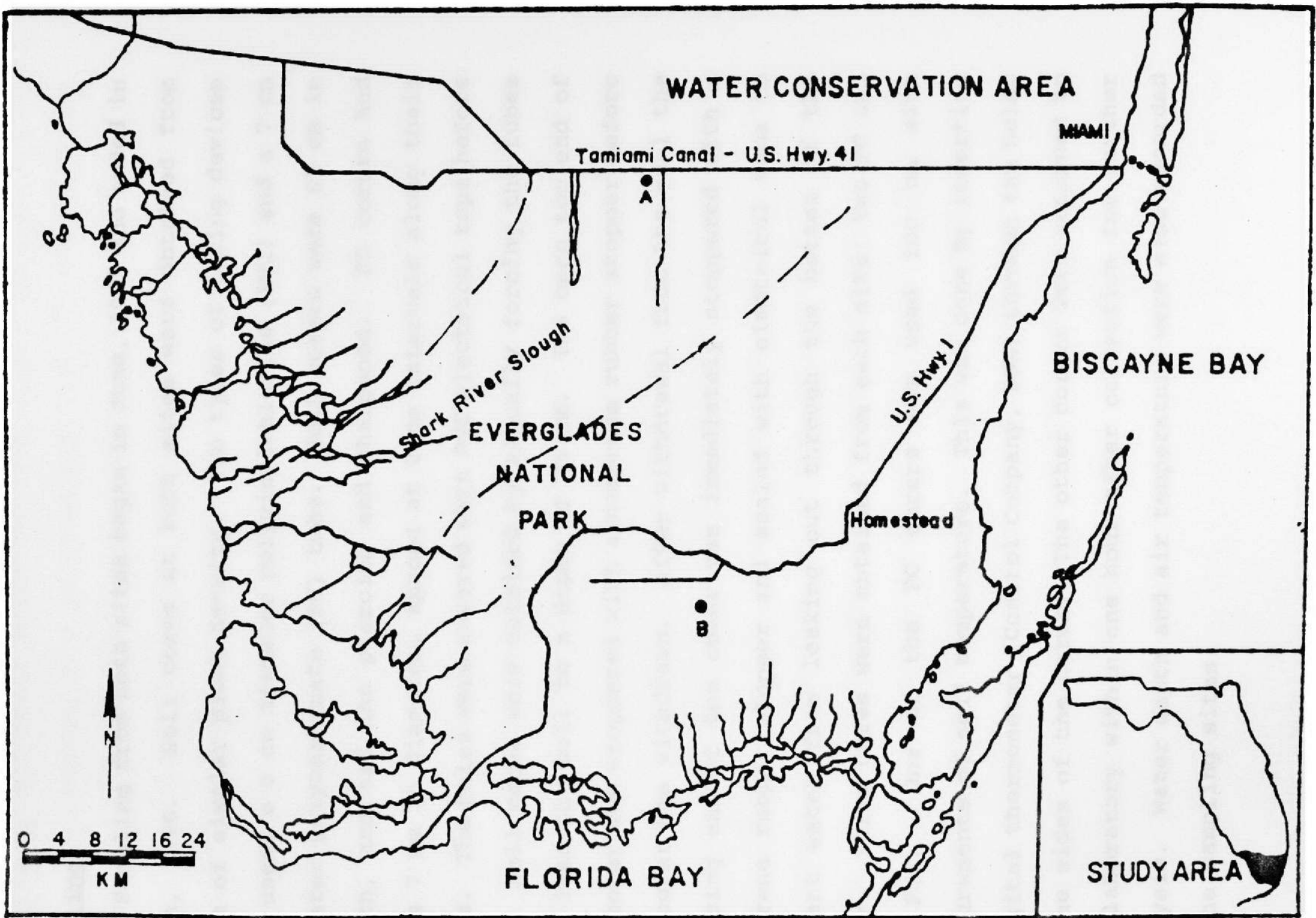

Fig. 1. Location of study sites: with marl soil.

(A) sawgrass marsh with peat soil, (B) sawgrass marsh 
Sampling

Sampling from both sites began in June, 1989 and ended in March, 1990. Soil cores at both sites were obtained from areas of similar plant density. Two types of coring devices were used; a $5 \mathrm{~cm}$ diameter polyvinylchloride (PVC) and a $7 \mathrm{~cm}$ diameter polycarbonate $(P C)$ tube. Both corers were $80 \mathrm{~cm}$ in length, and had the piercing end sharpened. PC corers had holes $7 \mathrm{~mm}$ in diameter, spaced at $2 \mathrm{~cm}$ intervals along their sides. The holes were covered with PVC electrical tape before use. Soil cores were obtained by manually forcing the tubes down into the soil to a depth of $25 \mathrm{~cm}$. The open top end of the corer was stoppered with a neoprene rubber stopper before the corer was withdrawn. After withdrawal from the soil the piercing end of the corer was immediately stoppered with a neoprene rubber stopper and sealed with electrical tape to prevent water from leaking out through the bottom of the corer. Three cores were obtained from each site; two PC and one PVC. One of the PC corers was used for on site measurements of soil temperature. This was done by inserting a digital thermometer (Control Company, USA) through the holes in the sides of the corer. The other corers were returned to the laboratory within one hour after collection for further analysis. Water depth and air temperature were also recorded at the sampling sites. 


\section{Sample Processing}

The $\mathrm{pH}$ and redox potential (Eh) of the soil in the PC corer were measured at $2 \mathrm{~cm}$ intervals from the bottom of the core upwards, by inserting the $\mathrm{pH}$ and Eh electrodes into the taped holes along its length. These holes were taped after each individual measurement to prevent water movement down the core since this could alter the Eh of the soil. A combination spear-tip pH electrode (model number 8163 orion Research Inc., Boston, $M A$ ) was used and Eh was measured using a platinum electrode with a calomel reference electrode (Fisher Scientific Co., USA). Eh values were recorded 10 minutes after the electrode was inserted into the core and corrected by adding the standard Eh for the calomel electrode (280 mV). Eh corrections due to changes in $\mathrm{pH}$ were not necessary because all $\mathrm{pH}$ values were within $0.24 \mathrm{pH}$ units of $\mathrm{pH} 7.4$. After the Eh measurements were made, the $\mathrm{pH}$ values were determined by placing the $\mathrm{pH}$ electrode in the holes that were used for the Eh measurements. The lack of surface water in the marshes at certain periods during the year prevented measurements of Eh and $\mathrm{pH}$ but allowed measurements of temperature of the soils. Methanogenesis determinations were conducted on samples taken by the PVC core. Each sample was extracted from core and sectioned in an anaerobic chamber (COY Laboratory Products Inc., Ann Arbor, MI $\left.\left(98 \% \mathrm{~N}_{2} ; 2 \% \mathrm{H}_{2}\right)\right)$. 


\section{Soil Preparation}

\section{Depth Profiles}

Under anaerobic conditions the top $18 \mathrm{~cm}$ of the core was sectioned at $2 \mathrm{~cm}$ intervals and each subsection was placed in a sterile petri plate. The soil in each plate was mixed until it appeared homogenous, and 3-ml portions of the $2 \mathrm{~cm}$ subsections were then placed in each of four 30-ml pre-weighed sterile head space sampler vials using a tipless $5-m 1$ syringe. Samples from each subsection were run in triplicate along with a heat-killed sample control. Controls were heat killed by placing the vials in boiling water for $45 \mathrm{~min}$.

Methanogenic Activity Depth Profile with Acetate

Eight sample vials from each subsection were prepared for the methanogenic activity depth profiles using acetate amendments. These included two triplicate sets and two controls. One triplicate set contained $1 \mathrm{ml}$ distilled water (water controls) and the other set contained $1 \mathrm{ml}$ of sodium acetate (final concentration $10 \mathrm{mM}$ ). Two heat-killed controls were used containing: (i) $1 \mathrm{ml}$ of water, and (ii) 1 $\mathrm{ml}$ acetate $(10 \mathrm{mM})$.

\section{Substance Additions}

To examine the effects of various compounds on methanogenesis soil was prepared as described above (depth profiles). Inorganic and organic compounds were kept as stock 
solutions (10 mM) and added to the sample vials. The inorganic compounds examined were sodium sulfate (final concentration, $3.33 \mathrm{mM})$, sodium sulfide $(3.33 \mathrm{mM})$, ammonium chloride $(3.33 \mathrm{mM})$ and sodium phosphate $(0.33 \mathrm{mM})$. The organic compounds were cellulose $(3.33 \mathrm{mg} / \mathrm{ml})$, glucose $(3.33$ $\mathrm{mM})$, sodium acetate $(3.33 \mathrm{mM})$. One set of water control vials, containing $1 \mathrm{ml}$ of distilled water and soil was analyzed for all experiments.

\section{Temperature Effects}

The top $10 \mathrm{~cm}$ of the core was mixed in a 100-ml beaker, until it appeared homogenous and added to sample vials in sets of four as above (depth profiles). One set of vials was used for each incubation temperature $\left(10,20,25,30,40\right.$ and $\left.50^{\circ} \mathrm{C}\right)$.

\section{Analysis}

After the additions, all sample vials were sealed with rubber serum stoppers and removed from the anaerobic chamber. The sample vials were then crimp sealed, evacuated and refilled with $\mathrm{N}_{2}$ five times to a final pressure of $1 \mathrm{~atm}$. A set of triplicate standard vials without soil containing 3-ml of water and $\mathrm{CH}_{4}(102 \mathrm{ppm}$ at $1 \mathrm{~atm})$ were incubated with the experimental vials. Sample vials and triplicate standard vials for all experiments, except the temperature effect experiments, were incubated at $30^{\circ} \mathrm{C}$. Methane production was 
determined every 2 days, over an 8 day period. Gas samples were taken using an automated Head space sampler (Hewlett Packard 19395A, USA), connected to a gas chromatograph (Hewlett Packard 5890; poropack R column 80/100 mesh $2 \mathrm{~m}$ ), equipped with a flame ionization detector. Injector, column, and detector temperature were set at 150,50 , and $300^{\circ} \mathrm{C}$, respectively. Methane peaks were calculated with an ELAB integration package (OMS TECH, MIAMI FL.). At the end of 8 days the vials were opened and dried at $80^{\circ} \mathrm{C}$ for $48 \mathrm{~h}$ and dry weight for each sample was determined. Methanogenic rates were normalized to their dry weights and volumes. The standard vials were used to convert the integrated areas of the $\mathrm{CH}_{4}$ peaks into $\mathrm{CH}_{4}$ concentration in $\mu$ moles per ml. Rates of methanogenesis were determined using the standard vials, experimental vials, incubation periods and samples dry weights or volumes (Appendix 1). Statistical analysis were performed on the experimental results, using a one way analysis of variance test (ANOVA). 


\section{RESULTS}

Time course experiments were performed to determine a suitable time interval for measuring methane production rates. The rates of increase in methanogenesis were highest during the 0-2 and 2-4 days time intervals (Fig. 2). After four days of incubation the rates of increase in methanogenesis decreased in both soil samples with the rates of methanogenesis in the peat samples approaching a relatively constant maximal value (Fig. 2).

Table. 1 Shows the temperature depth profile in the peat and marl for January and February 1990. There were small increases in temperature with increasing depth in the peat, however in the marl temperature decreased with depth. Temperatures in the marl ranged from 26.4 to 21.6 while in the peat temperatures ranged from 22.6 to 20.7 (Table. 1).

Eh and $\mathrm{pH}$ profiles in the peat and marl (Fig. 3) were similar; the Eh values were lowest at a depth of $4 \mathrm{~cm}$ in both soils, and the $\mathrm{pH}$ of the soils were relatively constant with depth. The methanogenesis profiles in peat and marl were also similar (Fig. 3), with the potential rates of methanogenesis decreasing with increasing depth in the soils. Normalizing the samples by dry weights to calculate methanogenesis changed actual values of methanogenesis but the profiles (Fig. 4b, c, d) were identical to those in Fig. 3. The rates of 


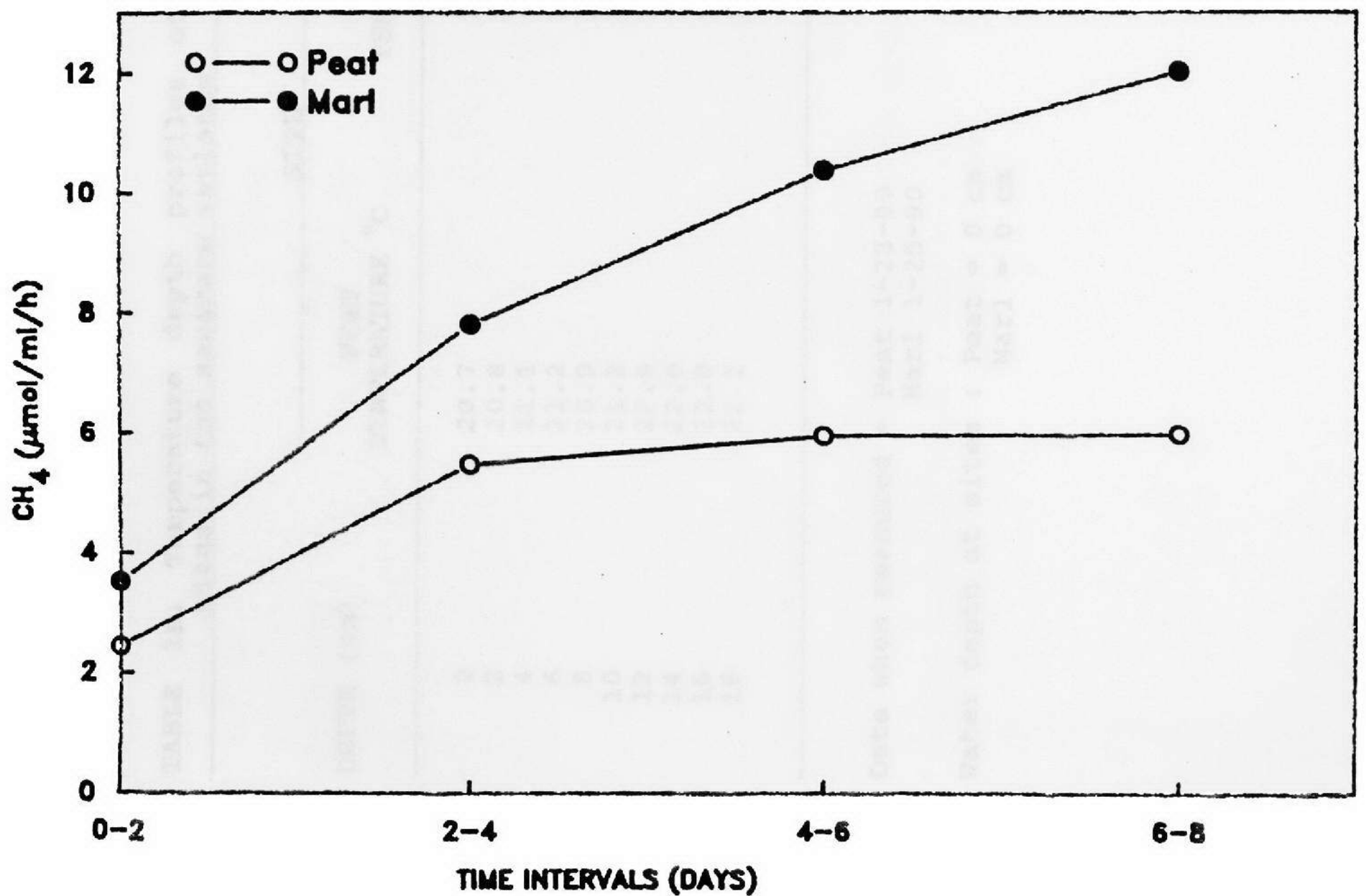

Fig. 2. Time course of methanogenesis in peat and marl solls 
TABLE 1a. Temperature depth profiles of the sample sites in the sawgrass wetlands

SITE

\begin{tabular}{rcc} 
DEPTH $(\mathrm{cm})$ & $\begin{array}{c}\text { MARL } \\
\text { TEMPERATURE }\end{array}$ & ${ }^{\circ} \mathrm{C}$ \\
\hline 0 & 20.7 & 26.0 \\
2 & 20.8 & 24.5 \\
4 & 21.1 & 23.1 \\
6 & 21.2 & 22.6 \\
8 & 20.9 & 21.8 \\
10 & 21.2 & 21.7 \\
12 & 22.6 & 21.6 \\
14 & 22.0 & 21.9 \\
16 & 22.0 & 23.1 \\
18 & 22.1 & 22.3
\end{tabular}

Date when measured $=$ Peat 1-23-90

Marl 1-25-90

Water depth at sites : Peat $=0 \mathrm{~cm}$ Marl $=0 \mathrm{~cm}$ 
TABLE 1b. Temperature depth profiles of the sample sites in the sawgrass wetlands

SITE

$\mathrm{DEPTH}(\mathrm{cm})$

PEAT
TEMPERATURE ${ }^{\circ} \mathrm{C}$

MARL

TEMPERATURE ${ }^{\circ} \mathrm{C}$

\begin{tabular}{rcc}
\hline 0 & 19.7 & 22.1 \\
2 & 19.4 & 20.8 \\
4 & 18.6 & 20.1 \\
6 & 18.7 & 19.9 \\
8 & 19.1 & 19.8 \\
10 & 19.6 & 19.8 \\
12 & 20.6 & 19.7 \\
14 & 20.3 & ND \\
16 & 20.7 & ND \\
18 & 20.6 & ND \\
\hline
\end{tabular}

* Not Determined

Date of measurement $=$ Peat 2-13-90

Marl 2-15-90

Water depth at sites : Peat $=0 \mathrm{~cm}$

Marl $=0 \mathrm{~cm}$ 

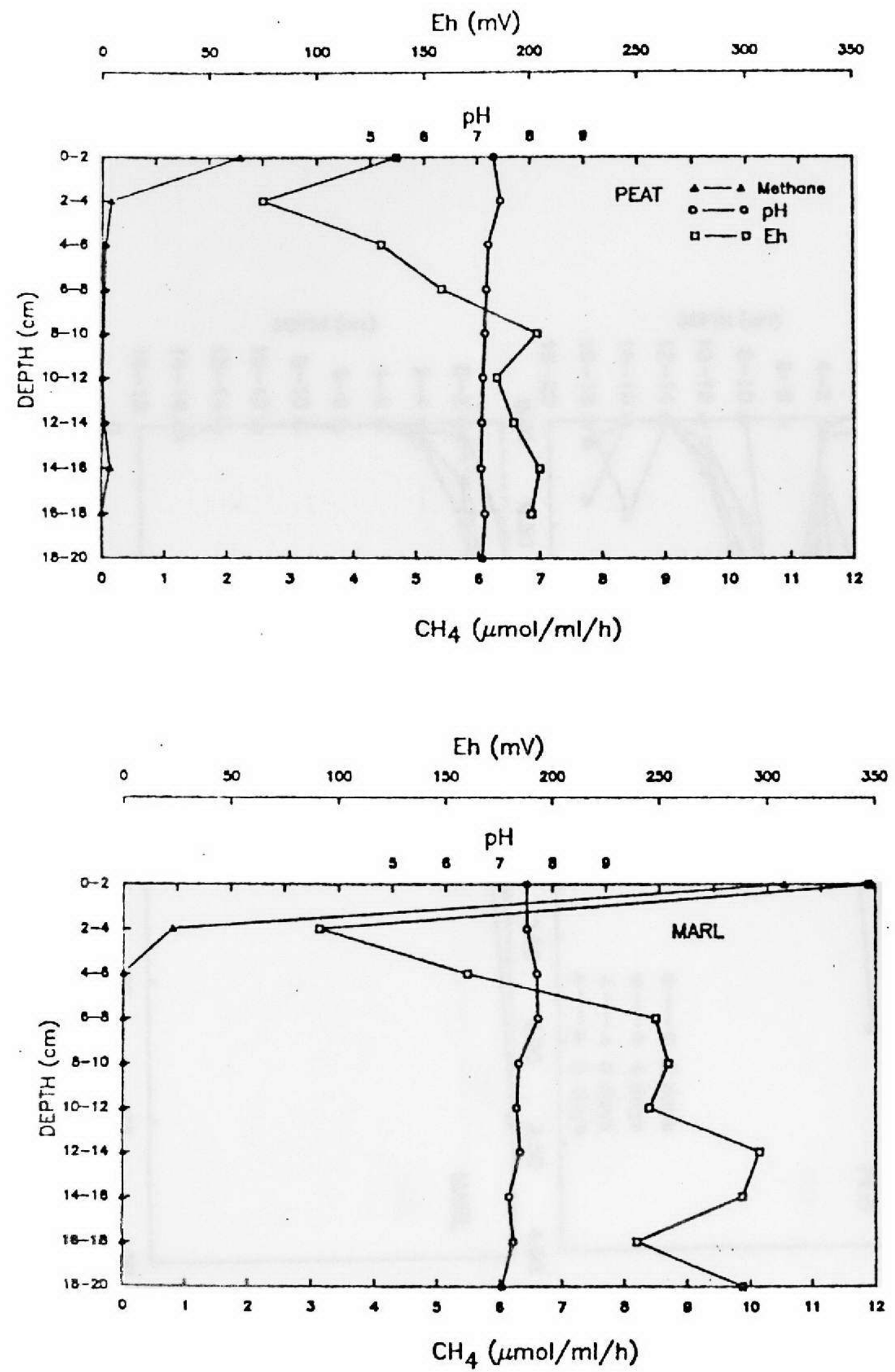

Fig. 3. Methanogenesis, $\mathrm{pH}$, and Eh depth profiles in peat and marl 


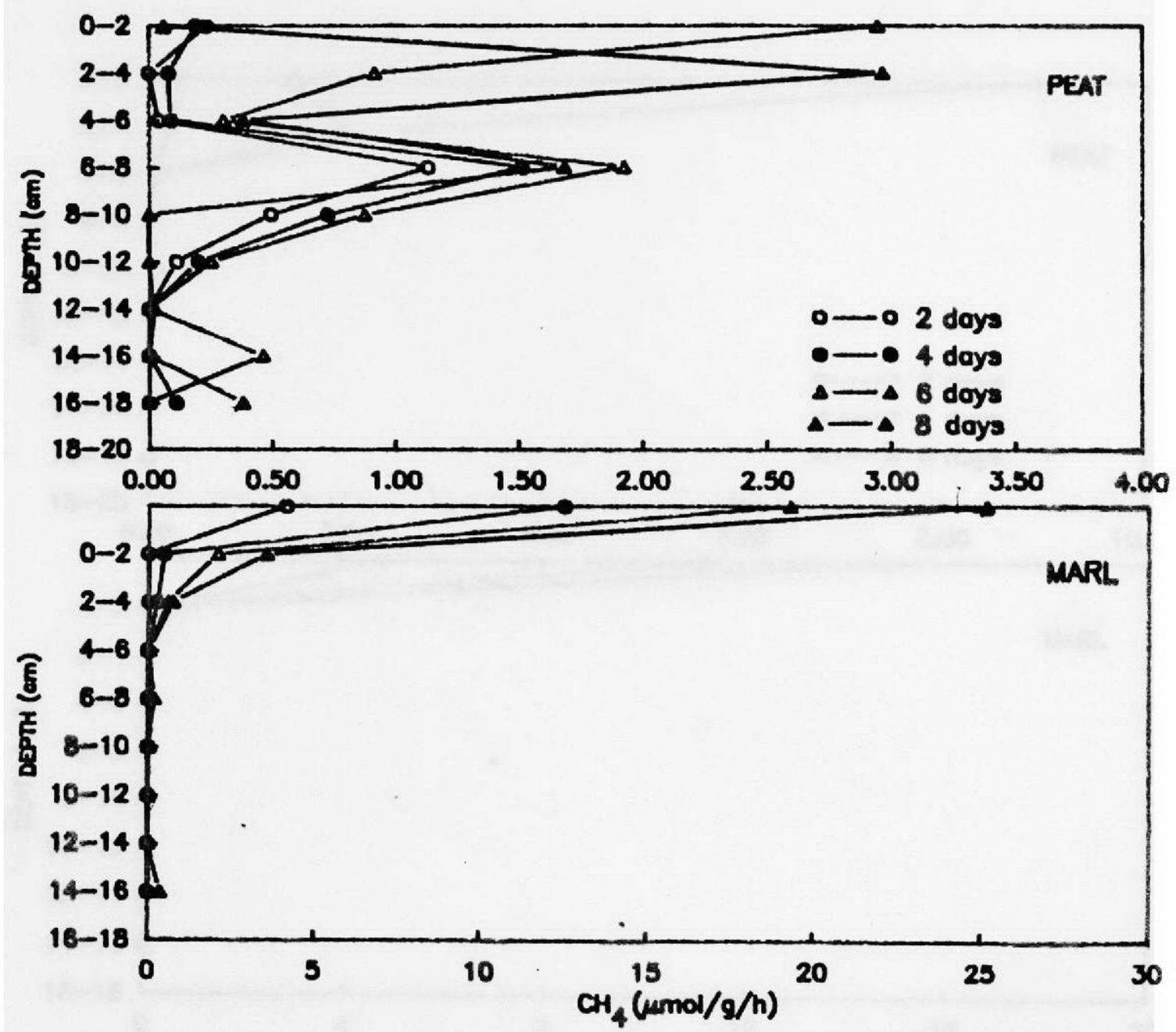

Fig. 4a. Comparison of methanogenesis in peat and marl soils in October following a heovy rainfall. 


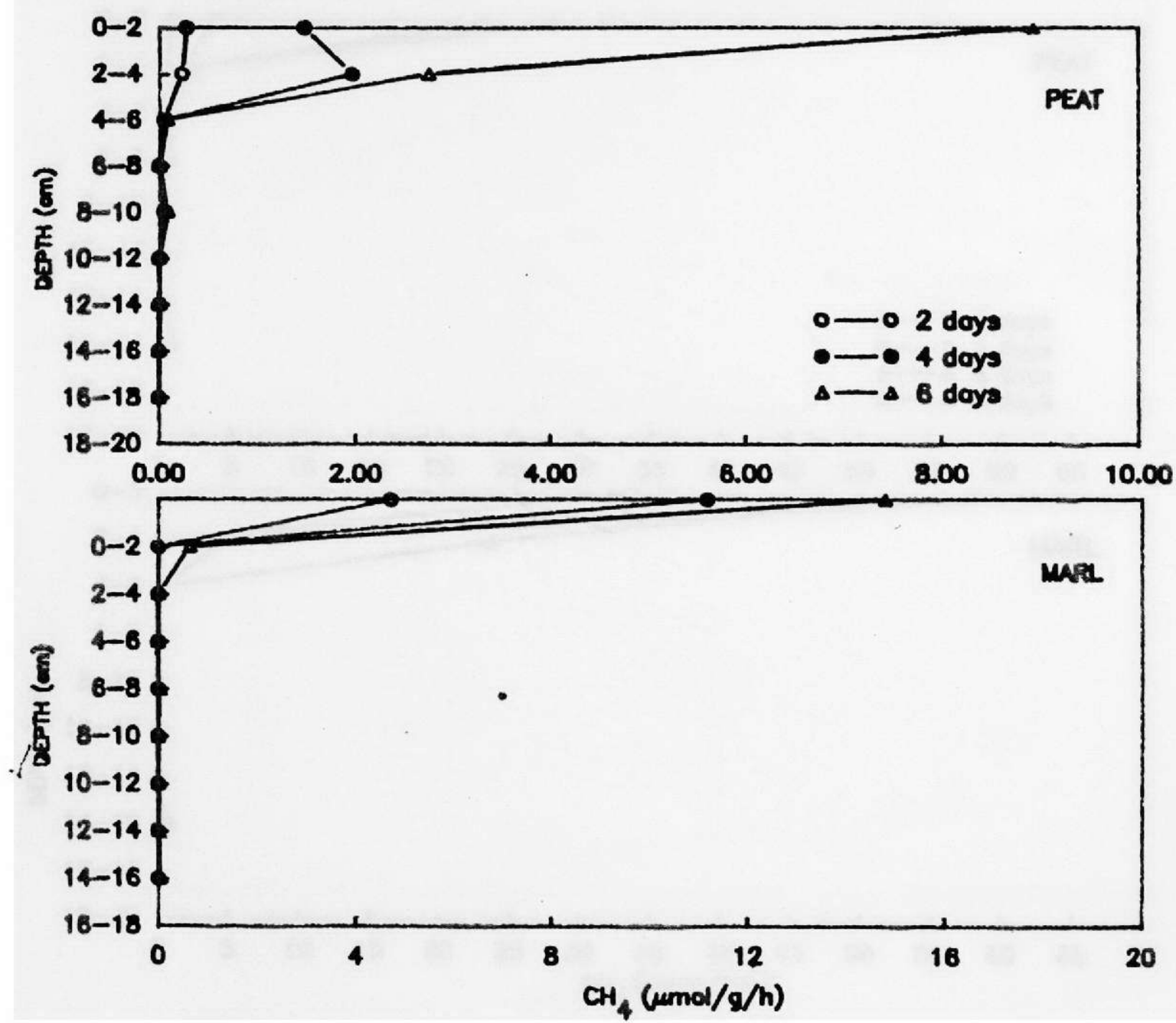

Fig. 4b. Comparison of methanogenesis in peat and marl soils 2 weeks after the experiment shown in 4a. 


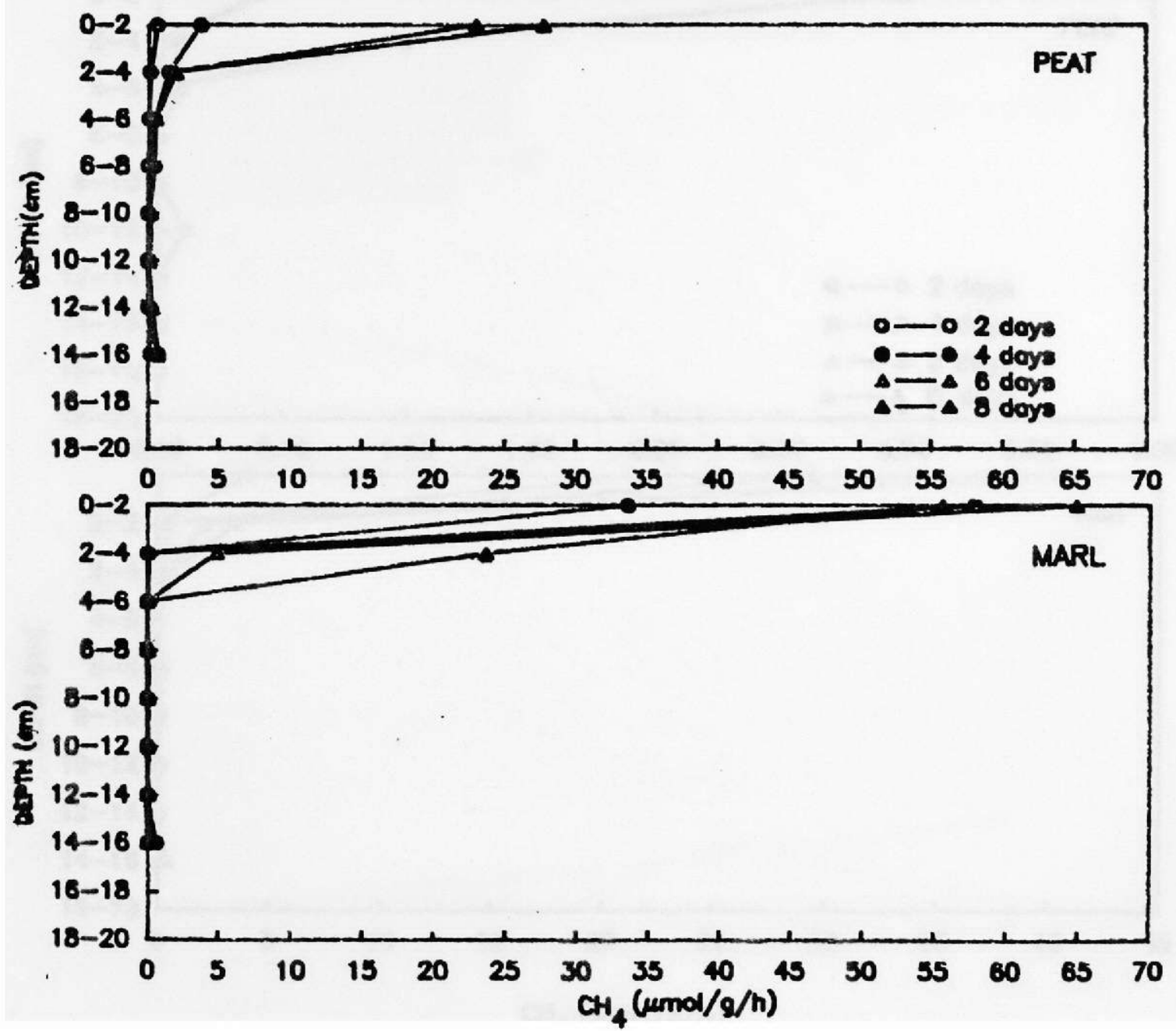

Fig. 4c. Comporison of methonogenesis in peot and mort soils 


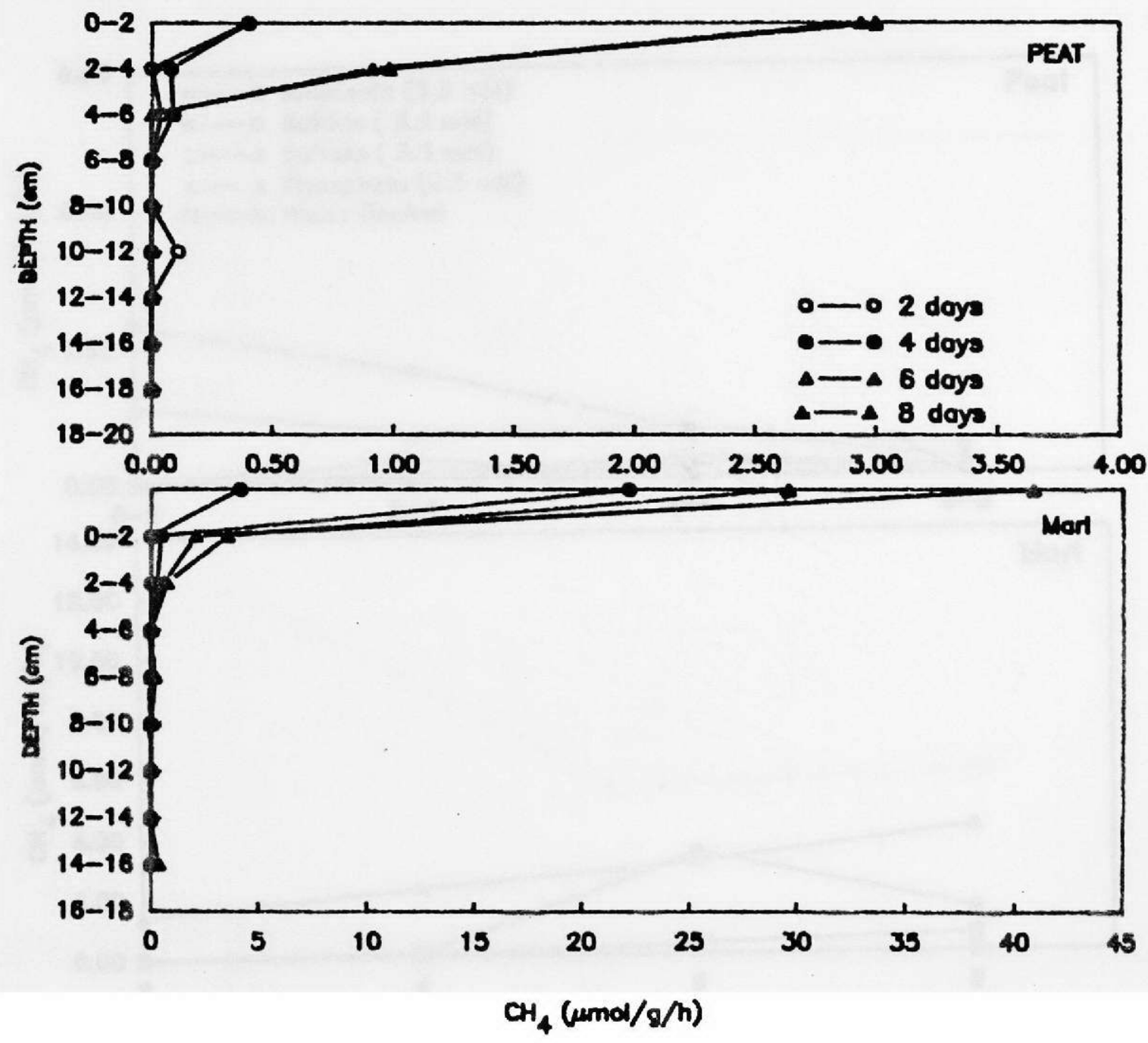

Fig. 4d. Comparison of methanogenesis in peat and mart soils 


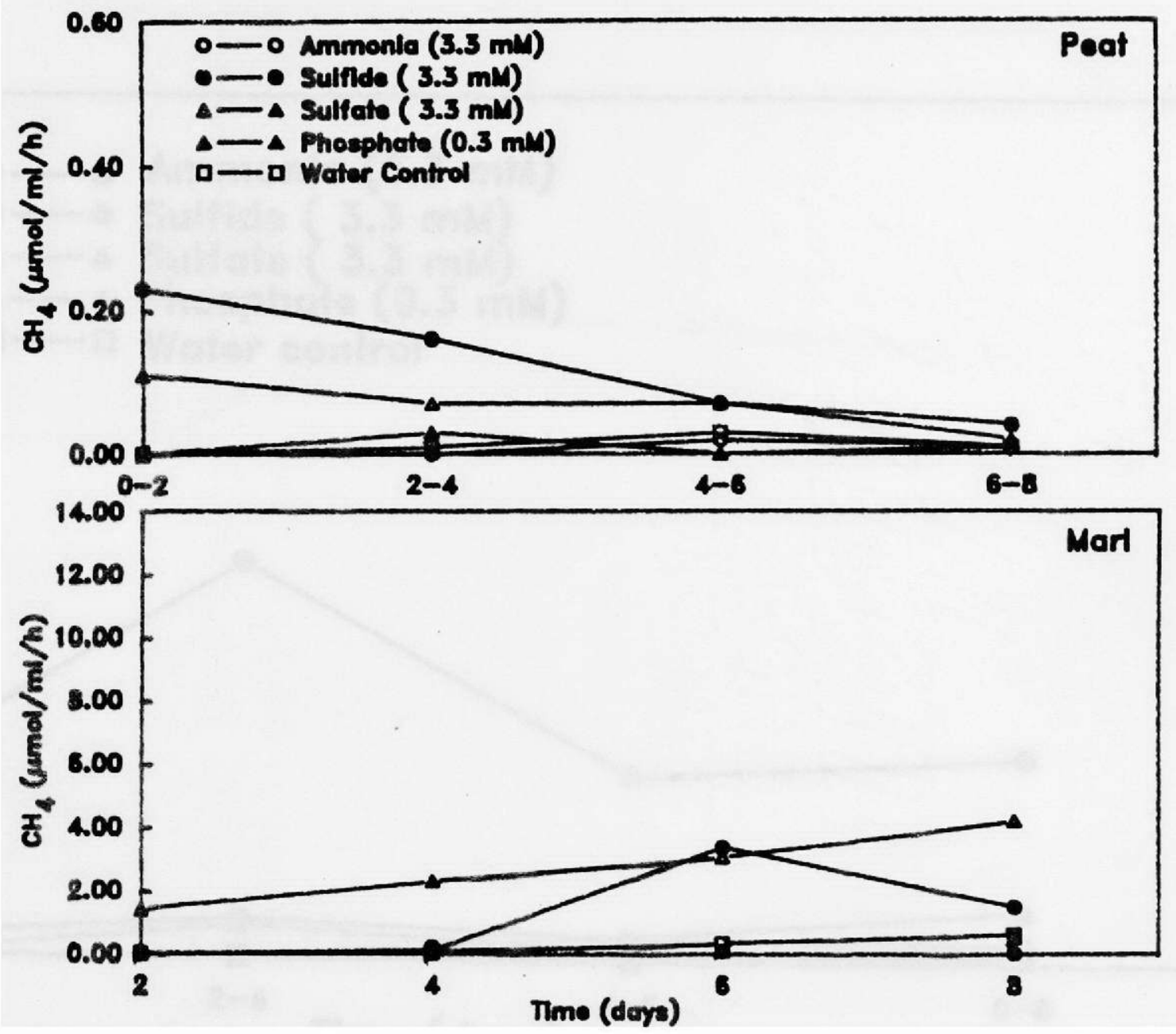

Fg. 5a. Effecta of Inorganic compounds on methanogertesis in peat and mant 


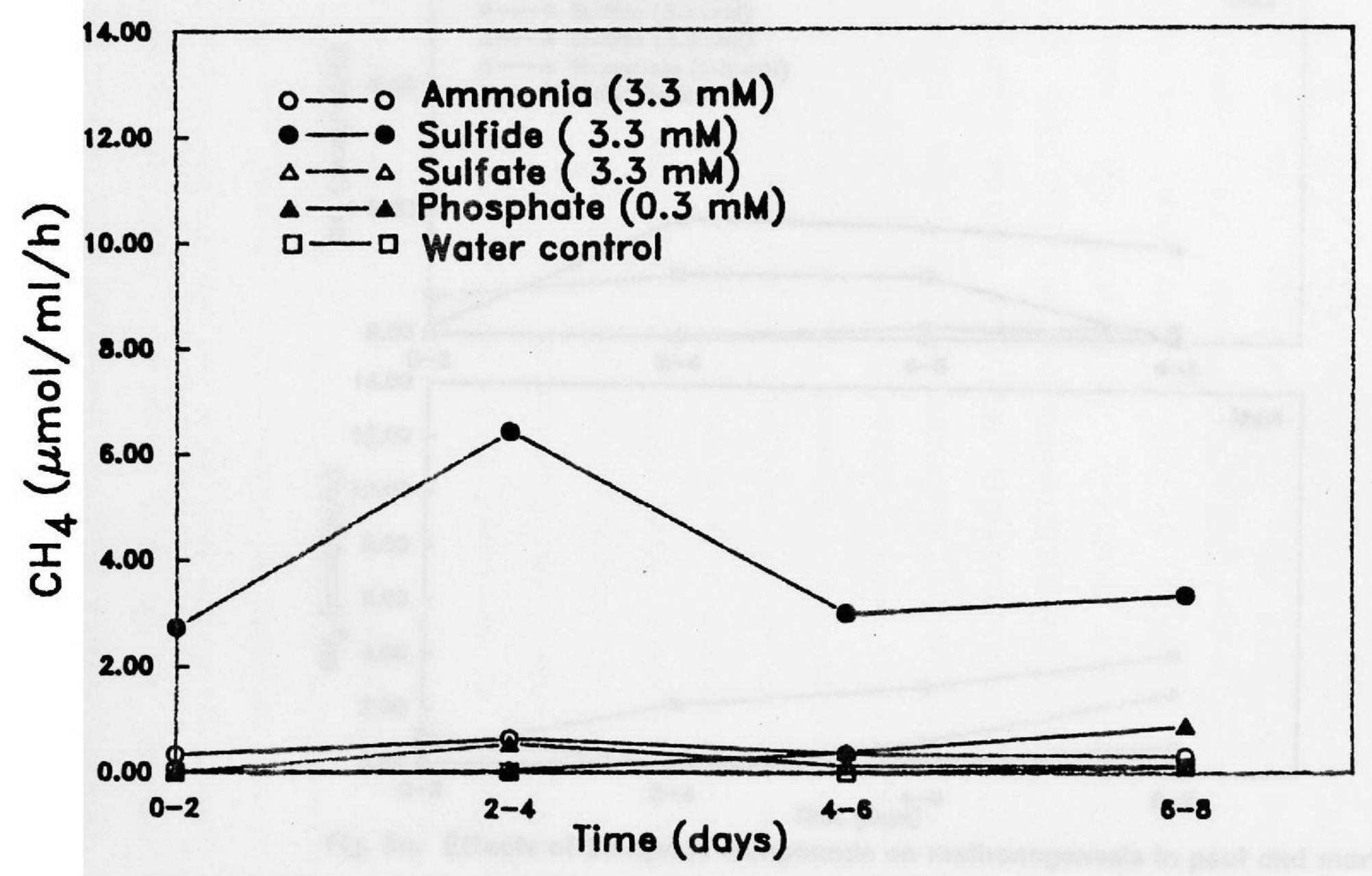

Fig. 5b. Effect of inorganic compounds on methanogenesis in marl 


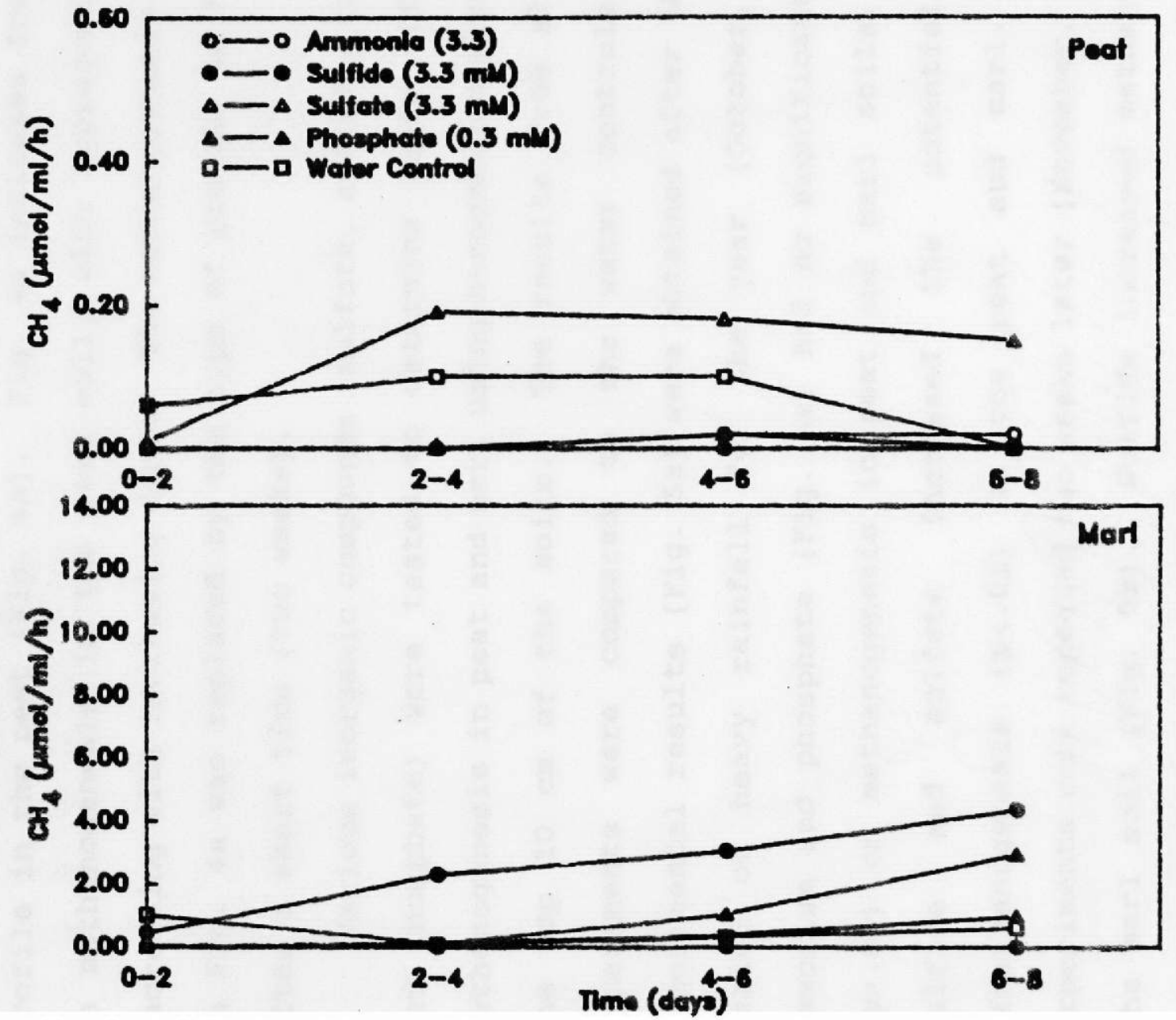

Fig. 5c. Effects of inorganic compounds on methanogenesis in peat and mart 
methanogenesis (Fig. 4) increased with increasing incubation periods of the soil samples. Profiles of methanogenesis potential in the marl were consistent with season (Fig. 4) but heavy rainfall in October 1989, changed the methanogenesis profile in the peat (Fig. 4a). Fig. 4 a indicates four peaks in methanogenesis in the peat soil, with subsequent peaks decreasing with increasing depth. The methanogenesis profile in Fig. 4a was replaced by the type of profile in Fig. 4b, after a short time (two weeks).

Various inorganic compounds (sulfate, sulfide, ammonium, and phosphate) were tested to determine their effects on methanogenesis in peat and marl using homogenized slurries of the top $10 \mathrm{~cm}$ of the soils. The results from all these experiments were compared to the water controls. The experimental results (Fig. 5a) were obtained after the first period of heavy rainfall for the year (October, 1989). Ammonium and phosphate (Fig. 5a) had no significant effect $(p>.05)$ on methanogenesis in peat and marl soils. While sulfide and sulfate increased the potential rates ofmethanogenesis $(p<.01)$ in the peat and marl. These experiments were repeated two weeks later (November, 1989) in the marl soil (Fig. 5b). Sulfide increased methanogenesis $(p<.001)$ and all the other inorganic compounds did not affect potential rates of methanogenesis. Experiments with these inorganic compounds were repeated again in January 1990 (Fig. $5 c)$. Sulfate significantly increased methanogenesis $(p<.01)$ 


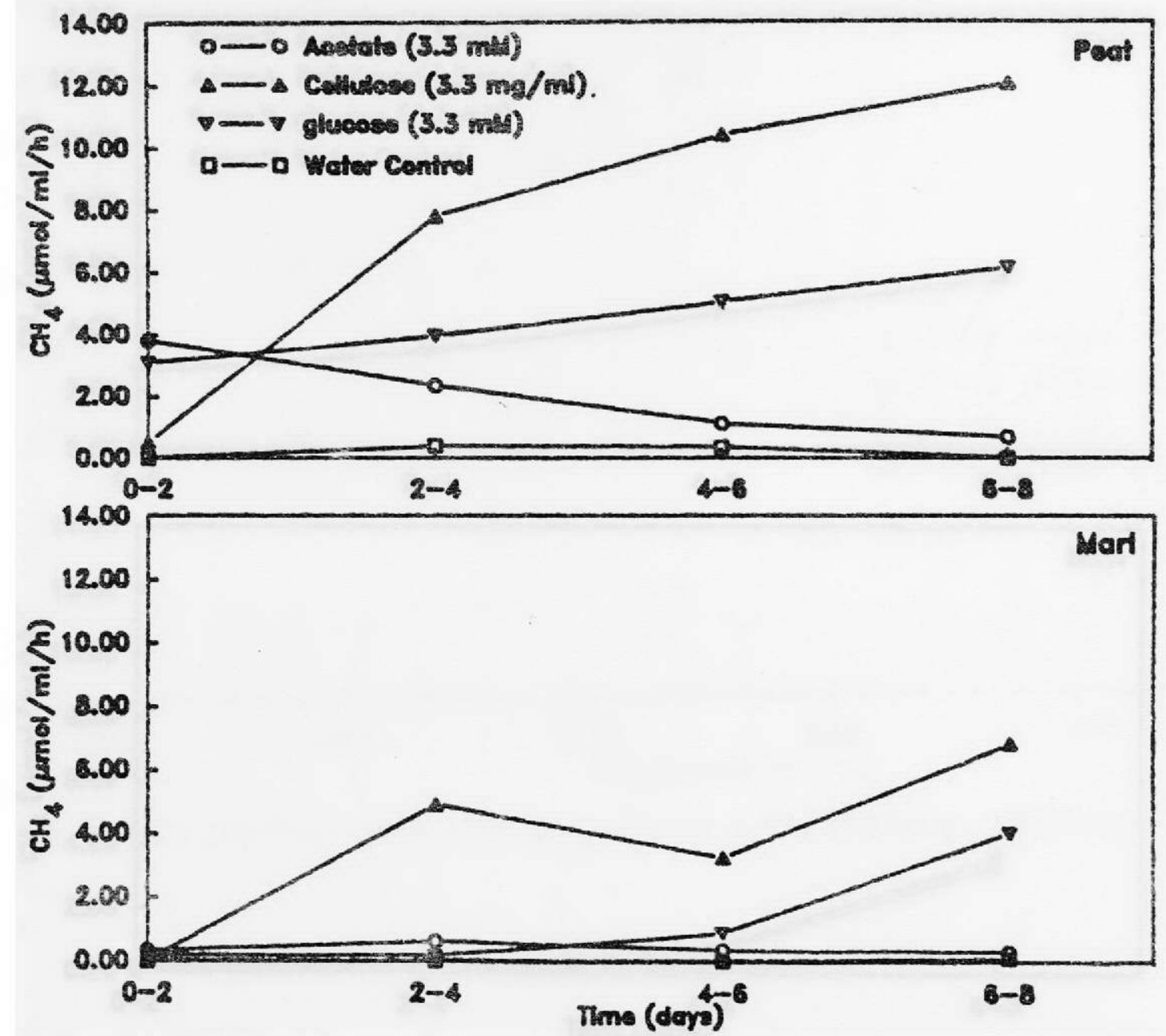

Fig. 6a. Effects of organic compounds on methanogenesis in peat and mart 

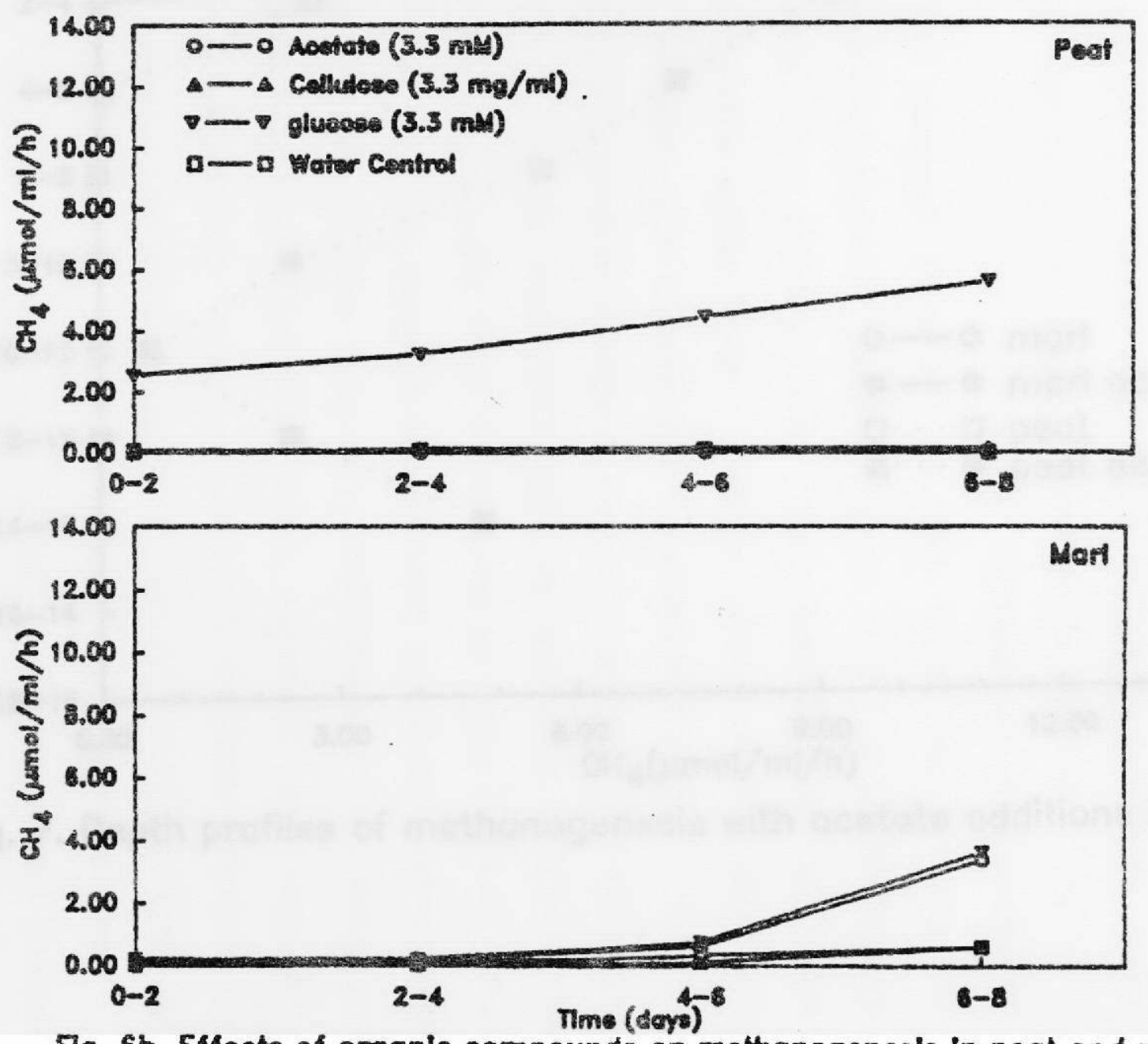

Fg. 6b. Effects of organle compounds on methanogenesis in peat and mart 


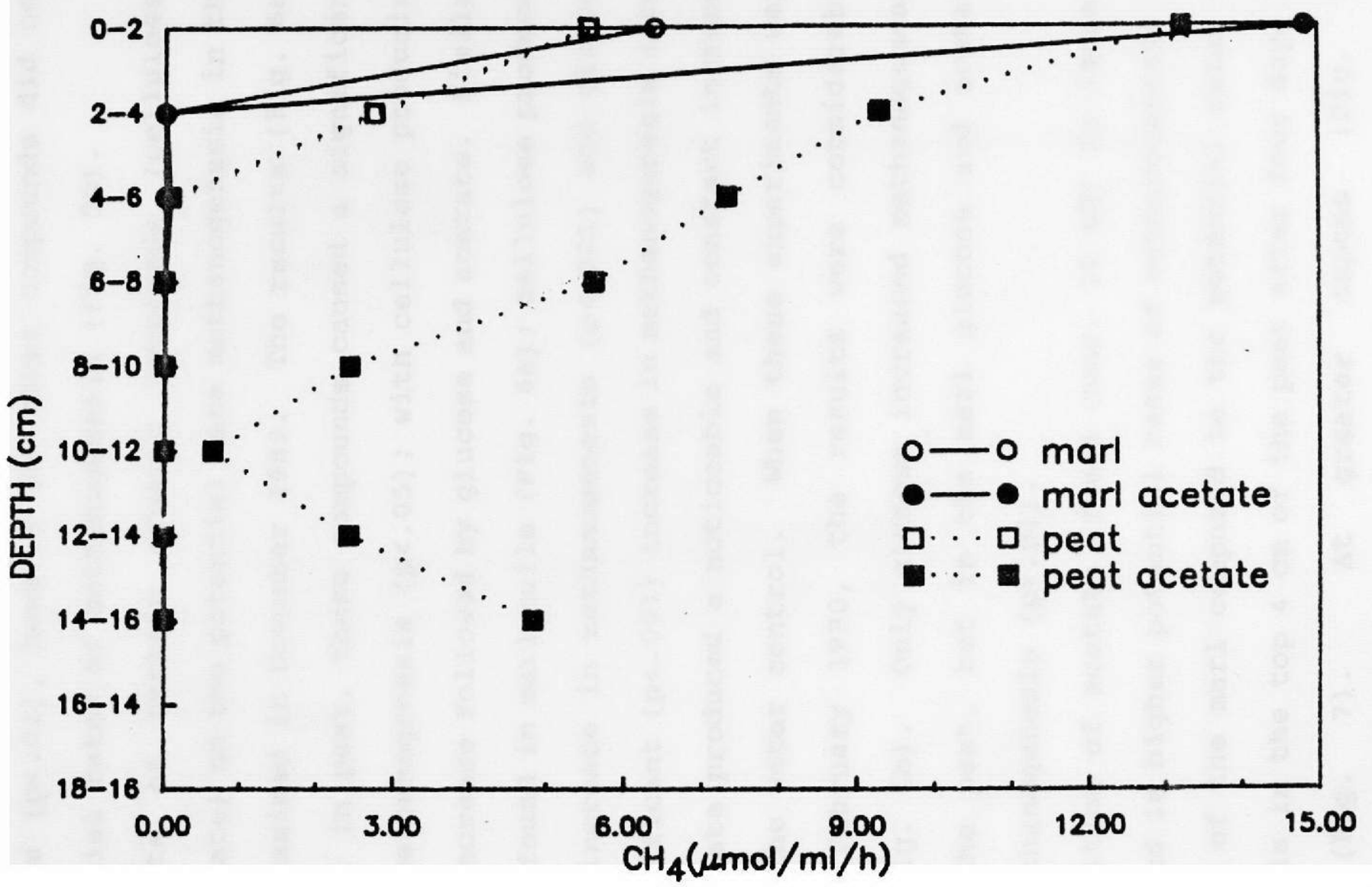

Fig. 7. Depth profiles of methanogenesis with acetate additions in peat and marl 
and the other inorganic compounds decreased methanogenesis $(p<.01)$. In the marl samples sulfide and phosphate increase methanogenesis $(p<.01)$, however the other compounds did not effect potential rates of methanogenesis (Fig. 5C).

The effects of certain organic compounds (cellulose, glucose, acetate) on the potential rate methanogenesis in the soils were examined in November 1989. The results (Fig. 6a) indicate that in peat, these compounds caused a significant increase in methanogenesis $(p<.05)$; with cellulose producing the largest increase followed by glucose and acetate. Similar results were found in marl soils (Fig. 6a); cellulose produced the largest increase in methanogenesis $(p<.001)$ and glucose caused a significant $(p<.001)$ increase in methanogenesis after 6 days. Acetate produced a noticeable and constant increase compared to the water control. When these experiments were repeated in February 1990, the results were considerable different (Fig. 6b). Only glucose increased methanogenesis $(\mathrm{p}<.01)$ in the peat, but in the marl glucose and acetate increased methanogenesis $(p<.01)$.

The addition of acetate (final conc. $10 \mathrm{mM}$ ) in January 1990, resulted in higher potential rates of methanogenesis in the top $4 \mathrm{~cm}$ of the marl compared to the potential rates of methanogenesis in the top $4 \mathrm{~cm}$ of the peat after four days of incubation (Fig. 7). At greater depths (Fig. 7) methanogenesis rates were higher in the peat than in the marl. The potential rate of methanogenesis increased with 

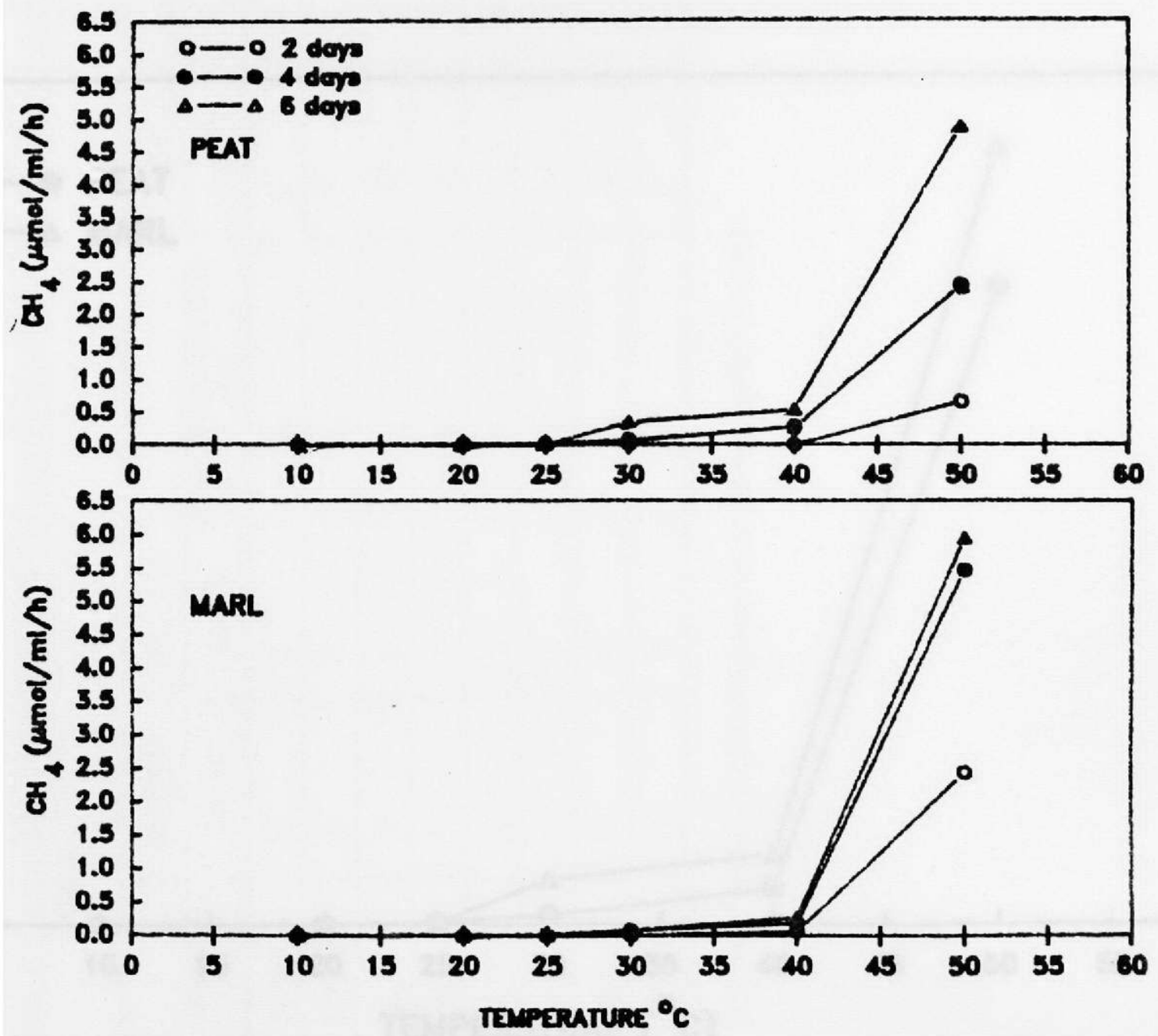

Fg. 80. Tomperature effect on methanogenesis in peat and mart 


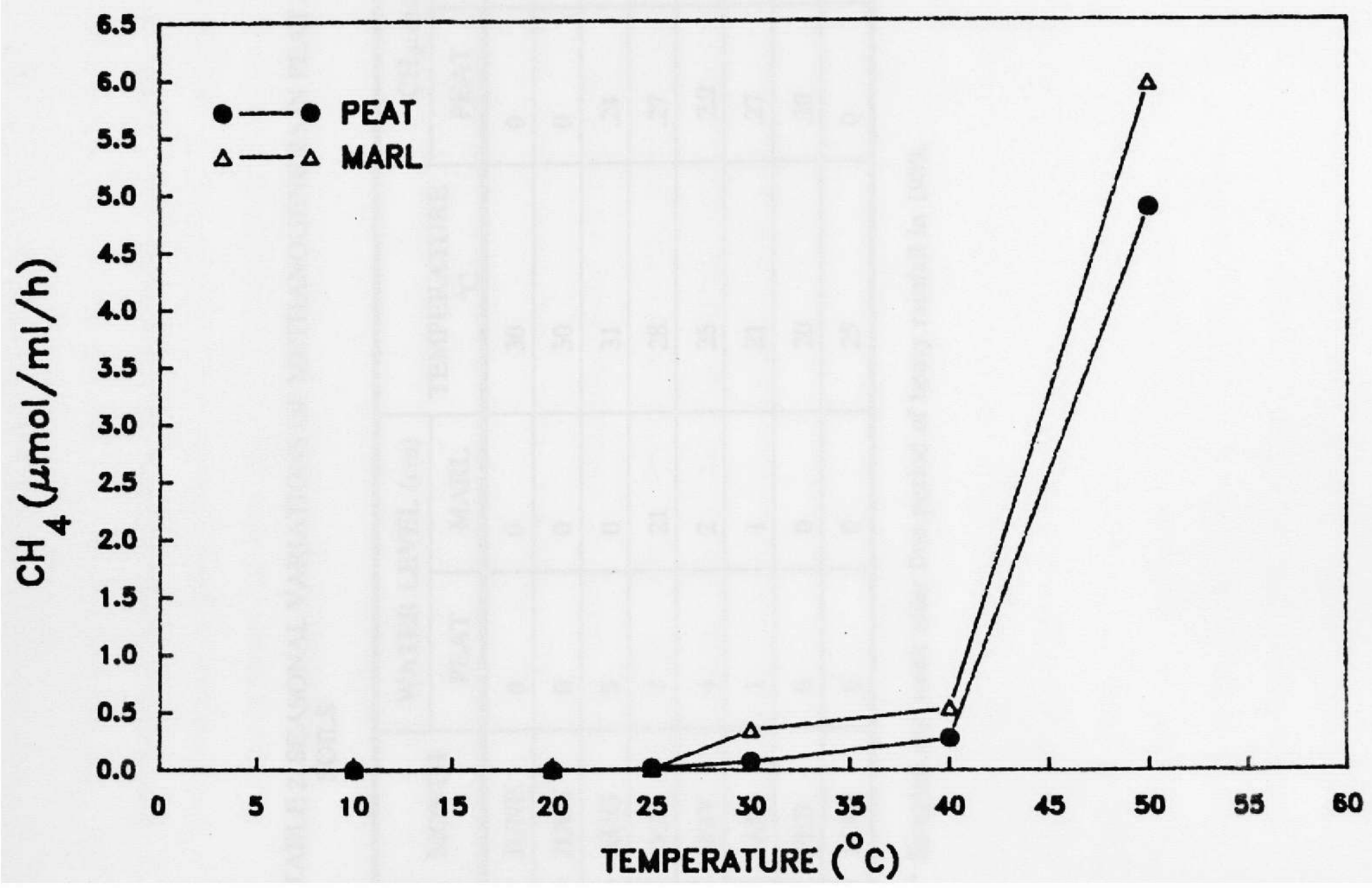

Fig. 8b. Temperature effect on methanogenesis in peat and marl 
TABLE 2. SEASONAL VARIATIONS OF METHANOGENESIS IN PEAT AND MARL SOILS

\begin{tabular}{|c|c|c|c|c|c|}
\hline \multirow{2}{*}{ MONTH } & \multicolumn{2}{|c|}{ WATER LEVEL (cm) } & \multirow{2}{*}{$\begin{array}{c}\text { TEMPERATURE } \\
{ }^{\circ} \mathrm{C} \\
\end{array}$} & \multicolumn{2}{|c|}{$\mathrm{CH}_{4} \mu \mathrm{mol} / \mathrm{ml} / \mathrm{h}$} \\
\hline & PEAT & MARL & & PEAT & MARL \\
\hline JUNE & 0 & 0 & 30 & 0 & 0 \\
\hline JULY & 0 & 0 & 30 & 0 & 0 \\
\hline AUG & 0 & 0 & 31 & .24 & 0 \\
\hline "OCT & 7 & 21 & 28 & .27 & .28 \\
\hline NOV & 4 & 2 & 25 & 2.2 & 10.55 \\
\hline JAN & 1 & 1 & 21 & .27 & 9.11 \\
\hline FEB & 0 & 0 & 20 & .10 & .35 \\
\hline MAR & 0 & 0 & 25 & 0 & 0 \\
\hline
\end{tabular}

* Sampled one week after first period of heavy rainfall in 1989. 
increasing temperature in peat and marl (Fig. 8). When the incubation temperatures were below $25{ }^{\circ} \mathrm{C}$ methanogenesis was insignificant in the soils and there were drastic increases in methanogenesis potential at incubation temperatures higher than $40{ }^{\circ} \mathrm{C}$.

Seasonal variation of methanogenesis potentials using the top $2 \mathrm{~cm}$ of soils between June, 1989 and March, 1990 (Table. 2) indicate that peat and marl had the highest potential rates of methanogenesis in November, 1989. During dry periods (e.g.: June, July) $\mathrm{CH}_{4}$ production decreased to undetectable levels in the soils. The effects of seasonal temperature changes on methanogenesis are not considered in Table 2 since all samples were incubated at $30^{\circ} \mathrm{C}$. 


\section{DISCUSSION}

Based on the results of the time course experiments (Fig. 2) a 4-6 day time interval was chosen as a suitable time interval to measure methanogenesis, for comparison studies of methanogenesis in peat and marl; since the increase in the rates of methanogenesis were relatively constant between 2-4 and 4-6 days. However, experimental results on methanogenesis from $0-2$ to $6-8$ are also presented.

Methanogenesis profiles in peat and marl were similar (Fig. 3), with the potential rates of methanogenesis decreasing with increasing depths in the soils. The actual values of the rates of methanogenesis varied at different times of the year in the peat and marl; however, profiles were consistent with season (Fig. 3). Williams et al.,(1984), obtained similar methanogenesis profiles from a Minnesota peatland, however in most northern peatlands methanogenesis peaks below $10 \mathrm{~cm}$ in the soil (Dinel et al., 1988). A major difference between the profiles of methanogenesis in Everglades wetlands and other freshwater wetlands is the sudden decrease of methanogenesis at a depth of $4 \mathrm{~cm}$ in the Everglades soils. This decrease in methanogenesis at $4 \mathrm{~cm}$ corresponds with a rapid increase in the Eh in both peat and marl soils (Fig. 3). This is understandable because lower Eh favors methanogenesis (Jarrell and Kalamokoff, 1987). The 
observation that methanogenesis occurred at soil Eh's above $300 \mathrm{mV}$ was attributed to the presence of microsites in the soil, that possess Eh's suitable for methanogenesis (Mayer and Conrad, 1989). The rate of methanogenesis in marl (Fig. 3) was approximately 10 times greater than the rate of methanogenesis in peat (Fig. 3) per unit volume $(p<.001)$. These results agree with the high levels of $\mathrm{CH}_{4}$ flux recorded in marl compared to peat marshes (Burke et al., 1988). Peat soils can oxidize up to $91 \%$ of the $\mathrm{CH}_{4}$ flux, while marl soils exibit negligible $\mathrm{CH}_{4}$-oxidation (King et al., 1990). Consequently, large proportions of organic carbon appear to be lost as $\mathrm{CH}_{4}$, from a sawgrass wetland with marl soil compared to a sawgrass wetland with peat soil. Heavy rainfall in October 1989, resulted in a change of the methanogenesis profiles in peat (Fig. 4a) from the methanogenesis profile shown in Figs. 3. The production of methane at greater depths in the peat was probably due to the movement of methanogenic substrates along with the water to greater depths in the soil. Although, methanogenesis occurred at greater depths in the peat (Fig. 4a), methane production rates were approximately $80 \%$ lower than later in that year. After two weeks methanogenesis profiles returned to the type of profiles shown in Figs. 3, 4b,c,d. These results (Fig. 4a) indicate that peat contains methanogens at depths greater than $4 \mathrm{~cm}$. Higher potential rates of methanogenesis in the marl soil site (site B) suggest that remineralization is more efficient in this 
environment. Thus, peat accumulation in site $A$ could be in part, due to low rates of methanogenesis, this could decreases fermentation and allows organic carbon to accumulate. Differences in potential rates of methanogenesis between peat and marl could not be accounted for by differences in the Eh, $\mathrm{pH}$ or temperature, since $\mathrm{Eh}$ and $\mathrm{pH}$ of peat and marl are similar to depths of $6 \mathrm{~cm}$ and all samples were incubated at $30^{\circ} \mathrm{C}$ (Fig. 3 ).

Several studies has found that methanogenesis increases with organic (e.g. cellulose, glucose) and inorganic compounds (e.g. Phosphates and ammonium) supplementation of a natural system (Holzapfel-Pschorn et al., 1989; Rudd and Taylor, 1980; Zeikus and Winfrey, 1976). Therefore it is possible that the difference in potential rate of methanogenesis in the peat compared to the marl resulted from an organic or inorganic compound limitation. Various inorganic compounds (sulfate, sulfide, ammonium, and phosphate) were tested to determine their effects on the potential rate of methanogenesis in peat and marl using homogenized slurries of the top $10 \mathrm{~cm}$ of soil. Sulfate and sulfide were used to lower the Eh of the soil, ammonium and phosphate were added to determine if these compounds were limiting methanogenesis in the soil. In October 1989, after heavy rainfall, ammonium and phosphate had no significant effect $(p>.05)$ on methanogenesis in either soil compared to the water control (Fig. 5a). This suggest that these substances are not limiting the rates of methanogenesis 
in the sawgrass marshes (peat and marl) during this period. Previous results (Fig. 4a) indicates that the potential rate of methanogenesis was very low in october 1989, possible due to a lack of suitable conditions for methanogenesis. During this period sulfide and sulfate increased methanogenesis $(\mathrm{p}<.01)$ in the peat and marl (Fig. 5a). Sulfide and sulfate additions improve reducing conditions, resulting in increase methanogenesis (Jarrell and Kalamokoff, 1987; Zeikus, 1977). Hence it appears that in October 1989 (two weeks after heavy rainfall) reducing conditions in the soils were not conducive for methanogenesis. In November 1989, the experiments were repeated in the marl soil but not in the peat soil. Sulfide increased methanogenesis $(\mathrm{p}<.001)$ in the marl (Fig. 5b) but the other substances did not affect methanogenesis. These results suggest that in November improving reducing conditions in the marl can increase methanogenesis. In January 1990, sulfate increased methanogenesis in the peat and sulfide increased methanogenesis in the marl, possible due to improvement of reducing conditions in the soils produced by these compounds (Fig. 5c). Phosphate increased methanogenesis $(p<.01)$ in marl (Fig. 5c), this suggest that in January phosphate concentration may be reduced in the Marl. The low levels of phosphate could have resulted from uptake of phosphate by algae and cyanobacteria, that formed thick overlaying mats in January 1990. Fig. 5 indicates that peat and marl are heterogenous environments that are affected by 
seasonality and methanogenesis rates can be increased by lower Eh.

The effects of various organic compounds (cellulose, glucose, acetate) on the potential rates of methanogenesis in the soils were examined in November 1989. The results (Fig. 6a) indicate that in peat soil, these compounds caused a significant increase in methanogenesis $(p<.01)$. Cellulose produced the largest increase in methanogenesis, followed by glucose and acetate. The notable increase in methanogenesis due to cellulose addition indicates that cellulose is fermented readily to methanogenic substrates in these soils. The delay in methanogenesis stimulation by cellulose was probably due to lag time necessary for cellulolytic and other fermentative organisms to convert cellulose into methanogenic substrates. Glucose had a favorable effect on methanogenesis. The delay prior to increased methanogenesis caused by glucose was short, since glucose is a monomer and is rapidly converted into methanogenic substrates. Acetate caused a rapid initial increase in methanogenesis in the peat that decreased steadily with time. This was not surprising since acetate is readily utilized by methanogens, and contains only one third as much carbon as glucose. The results for the marl (Fig. 6a) were similar to the peat (fig. 6a); cellulose produced the largest increase in methanogenesis $(p<.001)$ and glucose caused a significant $(\mathrm{p}<.001)$ increase in methanogenesis after 6 days. Acetate produced a noticeable 
and constant increase in methanogenesis compared to the water control.

When these experiments were repeated in February 1990, only glucose increased methanogenesis in peat and glucose and acetate increased methanogenesis in the marl (Fig. 6b). The lack of an increase in the potential rate of methanogenesis by cellulose was probably caused by a shift in the microbial community, due to low temperature and water level in the marshes (Table 2). Research in waste digesters has found that cellulitic bacteria are usually mesophiles or thermophiles (Maki, 1954). The increased in potential rates of methanogenesis in the marl but not in the peat produced by adding acetate in the soils, could be attributed to a larger percentage of methylothrophic methanogens in the marl. The high levels of algae and cyanobacteria in the marl, would result in high concentrations of substrates such as dimethyl sulfide and methylated amines which would select for methylothphic methanogens in the marl. Research in salt marshes and rice paddy have found that algal osmolites are oxidized to methanogenic substrates (e.g. dimethylsulfide) which select for methylothrophic methanogens (Franklin et al., 1988; Ragaopal and Daniels, 1988). Therefore, it appears that methanogenesis in peat and marl is limited by the availability of utilizable organic compounds that can be used directly as methanogenic substrates or fermented by microbes to methanogenic substrates. 
The results are consistent with similar studies from other aquatic soils (Pedersen and Sayler, 1980). Consequently, the high rates of methanogenesis observed in marl compared to peat indicate that some of the organic compounds found in marl are more amenable to microbial processing than the organic compounds found in peat. This could be attributed to the lack of microbial mats, in conjunction with the amount of lignin derived from sawgrass in the peat soil, since lignin is slowly fermented (Burke et al., 1988). One possible explanation is that the smaller sawgrass at site $B$ result in lower levels of lignin in the marl and a higher proportion of organic compounds derived from blue-green algae and bacteria (periphyton mats). Burke et al, (1988) concluded that the organic compounds derived from periphyton mats are highly soluble and are remineralized at a faster rate than organic compounds from sawgrass in these environments. Therefore, the production of methanogenic substrates by the periphyton mats in the marl could have increased the rate of methanogenesis resulting in increase oxidation of other complex compounds (e.g. lignin, cellulose) derived from sawgrass. It has been well documented that high rates of methanogenesis favors the production of more oxidized fermentative products that are methanogenic substrates (Zeikus.,1977; Rudd and Taylor., 1980). Thus mineralization of carbon into $\mathrm{CH}_{4}$ is a rapid and efficient process in the marl. It is possible that for methanogenesis to produce a 
significant increase in fermentation, the rate of methanogenesis must reach a certain threshold level. This threshold level of methanogenesis maybe achieved in marl soils but not in peat soils. Hence greater quantities of organic compounds would be available for conversion into $\mathrm{CH}_{4}$, with the subsequent loss in carbon as $\mathrm{CH}_{4}$ gas from the marl wetlands. This, then would prevent the accumulation of organic compounds as peat in site $B$.

The addition of acetate $(10 \mathrm{mM})$ resulted in higher rates of methanogenesis in the top $4 \mathrm{~cm}$ of the marl compared to the peat, but at greater depths $(>4 \mathrm{~cm}$ ) methanogenesis was higher in the peat than in the marl (Fig. 7). Peat soils appeared to contain more methanogens at greater depths than marl; assuming that methanogens (methylothrophic) in the peat and marl possessed equal capacity for utilizing acetate. The observation that peat soil contained methanogens at depths greater than $4 \mathrm{~cm}$ supports the results obtained in earlier experiments (Fig. 4). The failure of acetate to stimulate methanogenesis at depths greater than $4 \mathrm{~cm}$ in the marl could be attributed to: (a) increased Eh of the marl with increasing depth, (b) highly mineralized nature of the marl, (c) low porosity of marl that restricts water movement to greater depths, and (d) insignificant number of methanogens lower in the marl. Apparently in marl, fermentative and methanogenic communities are restricted to the top $0-4 \mathrm{~cm}$ of the soil. Although microbial communities exist at greater depths in the 
peat, their activity is low under normal conditions and unlikely to improve fermentation processes in peat.

Recent research in the Everglades by Harris et al., (1988) did not report any significant correlation between soil temperature and $\mathrm{CH}_{4}$ emission. The results (Fig. 8) indicated a positive correlation between methanogenesis and increasing temperature in peat and marl. Similar dependency of $\mathrm{CH}_{4}$ flux on temperature has previously been noted in the Everglades by Baker-Blocker et al., (1976). Methanogenesis in peat and marl dropped to insignificant levels at temperatures lower than $25^{\circ} \mathrm{C}$ and increased rapidly at temperatures higher than $40^{\circ} \mathrm{C}$. The observation that the optimum temperature for methanogenesis was higher than the maximum ambient temperature is common (Zeikus and winfrey, 1976). Therefore, during the dry winter season when temperatures drop below $25^{\circ} \mathrm{C}$ methanogenesis should be negligible in the sawgrass marshes of ENP.

Seasonal variations of methanogenesis potentials between June, 1989 and March, 1990 using the top $2 \mathrm{~cm}$ of soils (Table 2) indicated that peat and marl had the highest potential rate of methanogenesis in November, 1989. The effects of seasonal temperature changes on methanogenesis are not considered in Table 2 since all samples were incubated at $30^{\circ} \mathrm{C}$. The sawgrass marshes were inundated at the end of September, 1989 and the water depth was highest in October, 1989. However, methanogenesis was quite low during this 
period because conditions (such a low Eh) that favor methanogenesis were not at their optimum until November. During dry periods (e.g.: June, July) $\mathrm{CH}_{4}$ production was undetectable in both peat and marl. This requirement for water was also noticed by Harris et al., (1988). Although water is necessary for methanogenesis, water depth does not seem to affect the potential rates of methanogenesis.

Another factor affecting $\mathrm{CH}_{4}$ emissions in wetlands is $\mathrm{CH}_{4}$-oxidation. Although not specifically measured in this study, in other wetland (peatland) ecosystems between $11 \%$ and $100 \%$ of biogenic $\mathrm{CH}_{4}$ is susceptible to biological oxidation (Yavitt et al., 1988). Recent research in the Everglades has indicated that up to $91 \%$ of $\mathrm{CH}_{4}$ flux from peat wetlands was consumed by oxidation and in marl wetlands there was negligible $\mathrm{CH}_{4}$-oxidation (King et al., 1990). However the study sites used by King et al., 1990 are not representative of undisturbed wetlands in the Everglades and cannot be used to quantify $\mathrm{CH}_{4}$-oxidation at our sites. Undoubtedly, $\mathrm{CH}_{4}-$ oxidation would reduce $\mathrm{CH}_{4}$ flux and affect carbon cycling in our sites also. Therefore, to fully understand the significance of the methanogenic food web in carbon cycling in the Everglades, future research should study $\mathrm{CH}_{4}$-oxidation in undisturbed areas of these wetlands. 


\section{CONCLUSIONS}

Potential rates of methanogenesis were considerably greater in sawgrass wetlands with marl soils than in peat soils. An accurate determination of the effect that methanogenesis has on carbon cycling in these wetlands cannot be established without information on the portion of $\mathrm{CH}_{4}$ that is oxidized. However the results of our experiments supports the hypothesis that methanogenesis is an important process in carbon cycling in marl soils. Depth profiles of methanogenesis in peat and marl are similar, with a decrease with increasing depth. Maximum rates of methanogenesis occur in the top layers $(0-4 \mathrm{~cm})$ of the soils. This layer of the soil corresponds to regions of lowest Eh. Peat exhibits a greater potential for methanogenesis at greater depths with acetate as a substrate compared to the marl. Methanogenesis in peat and marl can be stimulated by cellulose, glucose and acetate; however, methanogenesis is unaffected by ammonium. Phosphate increased methanogenesis during certain periods of the year in the marl soil. Addition of sulfide and sulfate resulted in higher rates of methanogenesis. There was a positive correlation between methanogenesis and increasing temperature in these wetlands. When the water level dropped 
below the soil surface at both sites, methanogenesis was undetectable. A peak in methanogenesis potential occurred in November, 1988, one month after the wet season had started for that year.

Sawgrass wetlands with peat soils and marl soils are distinct environments. Periphiton mats cover the marl soils and may provide compounds that are readily fermented into methanogenic substrates. Methanogenesis in these areas is not equally affected by the same conditions (e.g. rain fall, organic and inorganic compounds) and these differences should be considered when methanogenesis or $\mathrm{CH}_{4}$ emissions are studied in these environments.

The high rates of methanogenesis in marl increase the efficiency of fermentation and remineralization in these wetlands, possibly limiting the accumulation of peat. 


\section{REFERENCES}

Baker-Blocker, A., T. M. Donahue, and K. H. Mancy. 1977. Methane flux from wetland areas. Tellus. 29:245-250.

Burke, R. A., T. R. Barber, and W. M. Sackett. 1988. Methane flux and stable hydrogen and carbon isotope composition of sedimentary methane from the Florida Everglades. Global Biogeochem. Cycles. 2:329-340.

Cappenberg, T. E. 1976. Methanogenesis in the bottom deposits of a small stratifying lake. pp.125-134. Microbial Production and Utilization of Gases. H. G. Schlegel, G. Gottschalk and N. Pfennig, E Goltze K. G., Gottingen. Ed.

Cicerone, R. J., and R. S. Oremland. 1988. Biogeochemical aspects of atmospheric methane. Global Biogeochem. Cycles. $\underline{2}: 299-327$.

Crill, P. M., K. B. Bartlett, R. C. Harriss, E. Gorham, E. S. Verry, D. I.'Sebacher, L. Madzar, and W. Sanner. 1988. Methane flux from Minnesota peatlands. Global Biogeochem. Cycles. 2 $2: 371-385$.

Dinel, H., S. P. Mathur, A. Brown, and M. Levesque. 1988. A field study of the effect of depth on methane production in peatland waters: Equipment and preliminary results. J. Ecol. 76:1083-1091.

Franklin, N. J., W. J. Wiebe, and W. B. Whitman. 1988. Populations of methanogenic bacteria in a Georgia salt marsh, Appl. Environ. Microbiol. 54:1151-1157.

Gleason, P. J., and W. Speckman. 1974. Calcareous periphyton and water chemistry in the Everglades. pp. 146-181. in Environments of South Florida: Present and Past. P. J. Gleason. Ed.

Harris, R. C., D. I. Sebacher, K. B. Bartlett, D. S. Bartlett, and P. M. Crill. 1988. Sources of atmospheric methane in the South Florida environment. Global Biogeochem. Cycles. $\underline{2}: 231-243$.

Hofstetter, R. H. 1983. pp. 201-244. Ecosystems of the World, Mires:Swamp, Bog, Fen and Moor. Regional Studies. A. J. P. Gore. Ed. Vol. 4B.

Holzapfel-Pschorn, A., R. Conrad., and S. Wolfgang. 1985. Production oxidation and emission of methane in rice paddies. FEMS. Microbiol. Ecol. 31:343-351. 
Jarrell, K. F., and M. L. Kalmokoff. 1987. Nutritional requirements of the methanogenic archaebacteria. Can. J. Microbiol. 34:557-576.

Jones, W. J., D. P. Nagle, Jr., W. B. Whitman. 1987. Methanogens and the diversity of archaebacteria. Microbiol. Rev. 51:135-177.

Khan, A. W., and T. M. Trottier. 1978. Effects of sulfurcontaining compounds on anaerobic degradation of cellulose to methane by mixed cultures obtained from sewage sludge. Appl. Environ. Microbiol. 35: $1027-1034$.

Kiene, R. P., R. S. Oremland, A. Catena, L. G. Miller, and D. G. Capone. 1986. Metabolism of reduced methylated sulfur compounds in anaerobic sediments and by a pure culture of an esterine methanogen. Appl. Environ. Microbiol. 52:1037-1045.

King, G. M., P Roslev, and H, Skovgaard. 1990. Distribution and rate of methane oxidation in sediments of the Florida Everglades. Appl. Environ. Microbiol. 56:2902-2911.

Loveless, C. M. 1959. A study of the vegetation in the Florida Everglades. Ecology. 40:1-9.

Maki, L. R. 1954. Experiments on the microbiology of cellulose decomposition in a municipal sewage treatment plant. Antonie Van Leeuwenhock J. Microbiol. And Serology. 20:185-200.

Martens and Berner. 1974. Methane production in the interstitial waters of sulfate depleted marine sediments. Science. 185:1167-1169.

Mayer, H. P., and R. Conrad. 1989. Factors influencing the population of methanogenic bacteria and initiation of methane production upon flooding of paddy soil. Microbiol. Ecol. 73:103-112.

Mountfort, D. O., and R. A. Asher. 1981. Role of sulfate reduction versus methanogenesis in terminal carbon flow in polluted intertidal sediment of Waimea Inlet, Nelson, New Zealand. Appl. Environ. Microbiol. 42:252-258.

Murray, P. A., and S. H. Zinder. 1984. Nitrogen fixation by a methanogenic archaebacterium. Nature. 312: $283-286$. 
Olmsted, I., and L. E. Loope. 1984. Plant Communities of Everglades National Park, in Environments of South Florida: Present and Past II. P. J. Gleason. Ed.

Oremland, R. S., L. J. Miller, and M. J. Whiticar. 1987. Sources and flux of natural gas from Mono Lake, Califonia. Geochim. Cosmochim. Acta. 51:2915-2929.

Oremland, R. S., and S. Polcin. 1982. Methanogenesis and sulfate reduction: Competitive and non-competitive substrates in esterine sediments. Appl. Environ. Microbiol. 44 $1270-1276$.

Parker, G. G. 1974. Hydrology of the pre-drainage system of the Everglades in southern Florida. pp. 18-27. in Environments of South Florida: Present and Past, P. J. Gleason. Ed.

Pedersen, D., and G. S. Sayler. 1981. Methanogenesis in freshwater soils: Inherent variability and effects of environmental contaminations. Can. J. Microbiol. 27: $198-205$.

Ragagopal, B. S., and L. Daniels. 1986. Investigation of mercaptans, organic sulfides, and inorganic sulfur compounds as sulfur sources for the growth of methanogenic bacteria. Curr. Microbiol. 14: $137-144$.

Rudd, J. W. M., and R. D. Hamilton. 1978. Methane cycling in a eutrophic shield lake and its effects on whole lake metabolism. Limnol. Oceanogr. 23:337-348.

Rudd, J. W. M., and C. D. Taylor. 1980. Methane cycling in aquatic environments. pp. 78-145. Advances In Aquatic Microbiology, vol.2. Droop, M. R. and H. W. Jannash. Ed. Academic Press Inc. (London) Ltd. 는 78-145.

Schonheit, P., J. K. Kristjansson, and R. K. Thauer. 1982 . Kinetic mechanism for the ability of sulfate reducers to out-compete methanogens for acetate. Arch. Microbiol. $\underline{132}: 285-288$.

Schutz, H., A. Holzapfel-Pschorn., R. Conrad, H. Rennenberg, and $W$. Seiler. 1989. A 3-year continuous record on the influence of daytime, season, and fertilizer treatment on methane emission rates from an Italian rice paddy. $\mathrm{J}$. Geophysical. Resch. 94:16405-16416. 
Steele, L. P., P. J. Fraser, R. A. Rasmussen, M. A. K. Khalil, T. J. Conway, A.J. Crawford, R.H. Gammon, K. A. Masarie, and K. W. Thoning. 1987. The global distribution of methane in the troposphere. J. Atmos. Chem. 5:125-171.

Stephens, J. C., 1974. Subsidence of organic soils in the Florida Everglades-A review and update. pp. 352-361. in Environments of South Florida: Present and Past. P. J. Gleason. Ed.

Williams, R. T., and R. L. Crawford. 1984. Methane production in Minnesota peatlands. Appl. Environ. Microbiol. $47: 1266-1271$.

Wilson, J. O., P. M. Crill, K. B. Bartlett, D. I. Sebacher, R. C. Harriss and R. L. Sass. 1989. Seasonal variation of methane emissions from a temperate swamp. Biogeochem. $\underline{8}: 55-71$.

Woese, C. R., L. J Magrum, and G. E. Fox. 1978 . Archaebacteria. J. Mol. Evol. 11:245-252.

Yavitt, J.B., and G. E. Lang. 1988. Potential methane production and methane oxidation rates in peatland ecosystems of the Appalachian Mountains, United states. Global Biogeochem. Cycles. 2:253-268.

Zehnder, A. J. B. and T. D. Brock. 1979. Methane formation and methane oxidation by methanogenic bacteria. J. Bacteriol. 137:420-432.

Zeikus, J. G., and M. R. Winfrey. 1976. Temperature limitation of methanogenesis in aquatic soils. Appl. Environ. Microbiol. 31:99-107.

Zeikus, J. G. 1977. The biology of methanogenic bacteria, Bacteriol. Rev. 41:514-541. 


\section{$\underline{\text { APPENDICES }}$}

APPENDIX

PAGES

A Formulas used for rates of methanogenesis calculations.. • . • • • • • • • • 57

B Table 1a. Redox potential (Eh) and pH measurements of the peat and marl sample sites. . . . . . . 59

C Table 1b. Redox potential (Eh) and $\mathrm{pH}$ measurements of the peat and marl sample sites. . . . . . . 60

D Table 1c. Redox potential (Eh) and $\mathrm{pH}$ measurements 
APPENDIX A

Calculation of methane concentration

(1) The amount of $\mathrm{CH}_{4}$ extracted from the sample vials, for analysis in the gas chromatograph has to be determined and corrected for. This is called the correction factor (CF) and is determined using the triplicate standard vials.

\section{Calculation of CF}

Average chromatograph value for the triplicate standard vials $=s_{n}$

Where $\mathrm{n}=$ run number

$\mathrm{N}=$ Number of runs

$$
C F=\left[\Sigma S_{n} / S_{n+1}\right] 1 / N
$$

Chromatograph value of a sample $=a$ Corrected chromatograph value $=\mathrm{a} * \mathrm{CF}=\mathrm{A}$

Corrected chromatograph value for a sample $=\mathrm{A}$ 
Average dry weight of sediment from a sample $(x)=w$ Corrected chromatograph reading of sample $(x)=x$ Average chromatograph reading of triplicate standard vial $=\mathrm{S}_{1}$ Average $\mathrm{CH}_{4}$ concentration in standard vials $\left(\mathrm{S}_{1}\right)=102 \mathrm{ppm}$ Therefore: $S_{1}=102 \mathrm{ppm}=100 \%$ Expressing $\mathrm{CH}_{4}$ conc. in $\mathrm{ppm}=102 / \mathrm{S}_{1} * \mathrm{x}=\mathrm{y}$

$$
\mathrm{m}=\mathrm{y} / \mathrm{w}
$$

\section{(3) Rate of methanogenesis}

Time (hours) between runs $=t$ rate of methanogenesis $=r=m / t$ To covert this rate into the rate of $\mathrm{CH}_{4}$ in $\mu \mathrm{mol} / \mathrm{g} / \mathrm{h}=\mathrm{R}$

$$
R=r / 22.4
$$


APPENDIX B

TABLE 1a. Redox potential (Eh) and pH measurements of the sample sites in the sawgrass wetlands

\section{SITE}

\begin{tabular}{|c|c|c|c|c|}
\hline \multirow{2}{*}{ DEPTH $(\mathrm{cm})$} & \multicolumn{2}{|c|}{ PEAT } & \multicolumn{2}{|c|}{ MARL } \\
\hline & $\mathrm{Eh}$ & $\mathrm{pH}$ & $\mathrm{Eh}$ & $\mathrm{pH}$ \\
\hline 0 & 296 & 7.58 & 305 & 7.61 \\
\hline 2 & 77 & 7.57 & 80 & 7.31 \\
\hline 4 & 103 & 7.35 & 160 & 7.20 \\
\hline 6 & 139 & 7.25 & 256 & 7.22 \\
\hline 8 & 154 & 7.25 & 286 & 7.05 \\
\hline 10 & 144 & 7.26 & 267 & 6.97 \\
\hline 12 & 130 & 7.22 & 290 & 6.92 \\
\hline 14 & 182 & 7.15 & 287 & 6.92 \\
\hline 16 & 200 & 7.12 & 266 & 6.89 \\
\hline 18 & 200 & 7.06 & 285 & 6.93 \\
\hline
\end{tabular}

Date of measurement $=10-12-89$

Water depth at sites : Peat $=9 \mathrm{~cm}$ Marl $=32 \mathrm{~cm}$

* these measurements were made using a silver chloride reference electrode and the lowest measurement was recorded. 
APPENDIX C

TABLE 1b. Redox potential (Eh) and pH measurements of the sample sites in the sawgrass wetlands

\begin{tabular}{|c|c|c|c|}
\hline \multirow{3}{*}{ DEPTH $\quad(\mathrm{cm})$} & \multicolumn{3}{|c|}{ SITE } \\
\hline & * PEAT & & \\
\hline & Eh $\quad \mathrm{pH}$ & Eh & $\mathrm{pH}$ \\
\hline 0 & & 289 & 7.51 \\
\hline 2 & & 129 & 7.51 \\
\hline 4 & & 127 & 7.40 \\
\hline 6 & & 142 & 7.07 \\
\hline 8 & & 195 & 7.10 \\
\hline 10 & & 293 & 6.97 \\
\hline 12 & & 245 & 6.96 \\
\hline 14 & & 287 & 6.82 \\
\hline 16 & & 315 & 6.89 \\
\hline 18 & & 318 & 6.88 \\
\hline
\end{tabular}

Date of mesurment $=10-17-89$

Water depth at sites : Marl $=21 \mathrm{~cm}$

* Peat site measurements were not determined. 
APPENDIX D

TABLE 1C. Redox potential (Eh) and $\mathrm{pH}$ measurements of the sample sites in the sawgrass wetlands

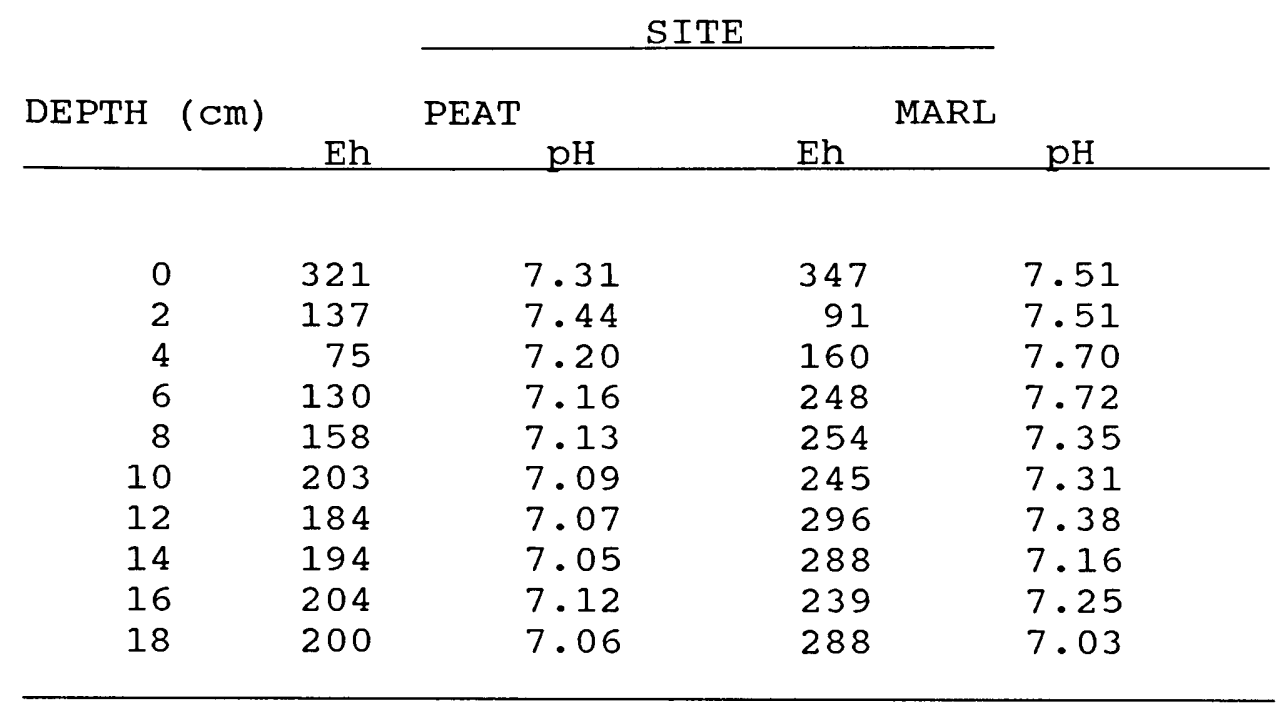

Date of measurment $=11-29-89$

Water depth at sites : Peat $=4 \mathrm{~cm}$ Marl $=2 \mathrm{~cm}$ 
VITA

Title of Thesis: Potential rates of methanogenesis in peat and marl sawgrass wetlands in the Florida Everglades.

Full Name: Dave Satnarine Bachoon

Place and Date of birth: September 3, 1963.

Port-of-Spain, Trinidad.

Elementary and Secondary Education:

Exchange Presbyterian School, 1969-1976. Trinidad Couva Junior Secondary School, 1976-1978. Trinidad Carapicharima Senior Comprehensive School, 1979-1982. Trinidad

Colleges and Universities:

Cembridge International Collage, 1983-1984. Toronto, Canada

Memorial University of Newfoundland, st. John's Newfounland, Canada. B. S. in Biology. 1984-1987. Florida International University, Department of Biological Sciences. M. S. in Biology. 1988-1990

Major Department: Biology

Date:

Signed: 